\title{
Lower crustal extension across the Northern Carnarvon basin, Australia: Evidence for an eastward dipping detachment
}

\author{
Neal W. Driscoll \\ Department of Geology and Geophysics, Woods Hole Oceanographic Institution, Woods Hole, Massachusetts
}

Garry D. Karner

Lamont-Doherty Earth Observatory of Columbia University, Palisades, New York

\begin{abstract}
Asymmetry and strain partitioning along conjugate margins are often explained in terms of detachment faults. Nevertheless, cogent evidence for their existence remains limited. Furthermore, even when inferred detachment faults are imaged seismically, it is difficult to demonstrate that differential displacement has occurred across these surfaces. We present tectonic and stratigraphic evidence from the Northern Carnarvon basin, northwest Australia, that documents the existence of an intracrustal eastward dipping detachment. By integrating sequence stratigraphy with kinematic and isostatic models of basin development, we conclude that the Northern Carnarvon basin was formed as a consequence of four extension events: (1) a broadly distributed late Permian event, (2) a predominantly localized Rhaetian event responsible for the inception of the Barrow and Dampier subbasins, (3) a localized Callovian fault reactivation within the Barrow-Dampier subbasins, and (4) a Tithonian-Valanginian event that generated large post-Valanginian regional subsidence across the Northern Carnarvon basin with only minor accompanying brittle deformation and erosional truncation. The regional distribution and amplitude of the post-Valanginian subsidence are not consistent with the minor amounts of TithonianValanginian brittle upper crustal extension observed on the margin. Large portions of the platform were emergent or at very shallow water depths prior to the Tithonian-

Valanginian extension. To match the distribution and magnitude of the post-Valanginian "thermal-type" subsidence requires significant lower crustal and mantle extension across the Northern Carnarvon basin. Such a distribution of extension implies the existence of an eastward dipping, intracrustal detachment having a ramp-flat-ramp geometry that effectively thinned the lower crust and lithospheric mantle. The detachment breached the surface close to the position of the continent-ocean boundary, west of the Exmouth

Plateau. The flat component of the detachment occurred at midcrustal depths $(\sim 15 \mathrm{~km})$ across the plateau and ramped beneath the Australian continent. Lower crustal ductile extension provides a viable mechanism to generate large regional subsidence with little attendant brittle deformation, which may explain the paradox that both sides of many conjugate margins appear to be the "upper plate."
\end{abstract}

\section{Introduction}

Many conceptual and theoretical models for extensional deformation of the lithosphere invoke shallow dipping crustal shear zones and/or low-angle normal detachments to explain the architecture and subsidence patterns observed along conjugate continental margins and basins [Royden and Keen, 1980; Tankard and Welsink, 1987; Lister and Davis, 1989; Mutter et al., 1989; Boillot and Winterer, 1988; Weissel and Karner, 1989; Lister et al., 1991; Abers, 1991; Wernicke, 1992; Boillot et al., 1995; Driscoll and Kamer, 1995; Driscoll et al., 1995]. The existence of low-angle normal detachments, however, remains controversial [Jackson, 1987; Anders and Christie-Blick, 1994]. Besides the theoretical considerations, the controversy over low-angle detachments is compounded by the fact that there is

Copyright 1998 by the American Geophysical Union.

Paper number 97JB03295.

0148-0227/98/97JB-03295\$09.00 a paucity of critical observations. We present key tectonic and stratigraphic evidence from the Northern Carnarvon basin that attests to the existence of a low-angle eastward dipping detachment. The Northern Carnarvon basin encompasses the Barrow, Dampier, and Exmouth subbasins as well as the Peedamullah shelf, Alpha Arch, and the Exmouth Plateau (Figure 1 [Copp, 1994]). Previous seismic reflection and refraction studies in the region proposed that a detachment fault exists across the Exmouth Plateau at the base of the sedimentary succession that dips toward the west and has a "duplex" geometry [Mutter et al., 1989]. However, the interpretation of an intrasedimentary detachment is not consistent nor supported by the stratal relationships, subsidence patterns, or the spatial and temporal distribution of the deformation observed across the Northern Carnarvon basin.

The northwestern Australian region consists of several geologic terranes: Archean and early Proterozoic cratons, Proterozoic basins, Paleozoic basins, and a series of Mesozoic and 
$112^{\circ}$

$114^{\circ}$ $116^{\circ}$

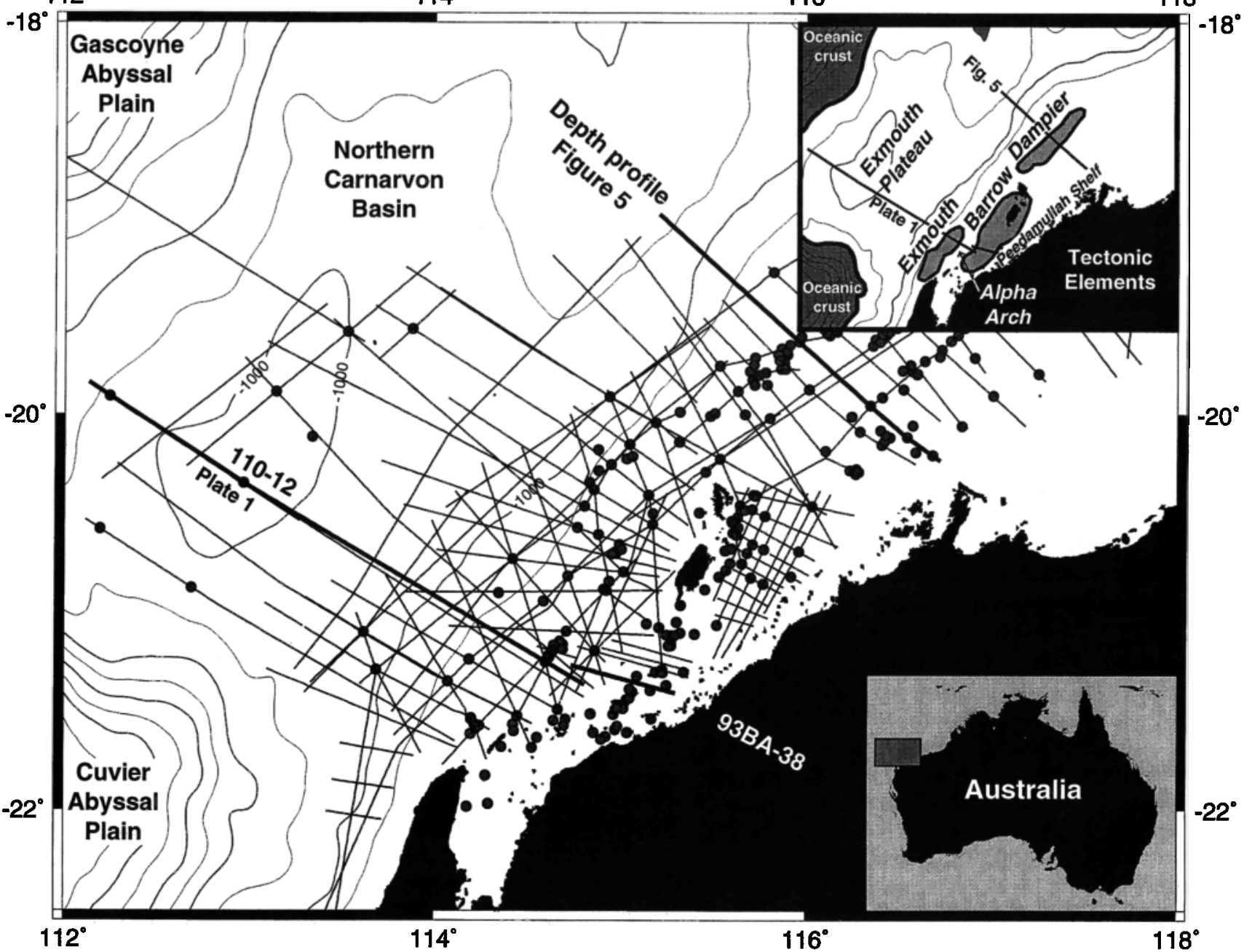

Figure 1. Location map of the northwestern Australian continental margin illustrating the spatial relationship among the Gascoyne and Cuvier Abyssal Plains and the northern Carnarvon basin. The Barrow, Exmouth, and Dampier subbasins have no bathymetric expression and are located beneath the present-day continental shelf. The Australian Geological Survey Organization (AGSO) 101 and 110, GECO-Prakla GPCT93, and Digicon 93BA series seismic reflection data as well as industry and Ocean Drilling Program (ODP) wells used in this study are shown. Lines AGSO 110-12 and 93BA-38 shown in Plate 1 and the depth profile shown in Figure 5 are denoted by heavy lines and are labeled accordingly.

Cenozoic basins. The onset of seafloor spreading propagated from north to south along the northwest Australian margin; in the Argo basin, seafloor spreading began during Callovian time (marine magnetic anomaly M25), whereas in the Gascoyne, Cuvier, and Perth basins, seafloor spreading began in Valanginian time (anomaly M10 [Exon et al., 1992; Boote and Kirk, 1989]). The Exmouth Plateau, a thinned and subsided continental block with a crustal thickness of $\sim 20 \mathrm{~km}$, forms part of the Northern Carnarvon basin (Figure 1). Previous seismic reflection studies across the Exmouth Plateau indicate that the preserved sedimentary succession consists of $\sim 5000 \mathrm{~m}$ of Paleozoic rocks, an average of $\sim 3000 \mathrm{~m}$ of Triassic sediments, and $\sim 1000 \mathrm{~m}$ of younger Cretaceous and Cenozoic sediments [Willcox and Exon, 1976]. The purpose of this paper is to define the tectonic significance of the sedimentary packages preserved on the Northern Carnarvon basin in terms of the extensional events responsible for the development of the margin. In particular, we will focus on the Tithonian-Valanginian extensional event to demonstrate the existence and importance of an eastward dipping detachment on margin development. Toward this goal, we apply an integrated approach that combines sequence stratigraphy and kinematic basin modeling to determine (1) the amount of space available for sediment accumulation across and along the Northern Carnarvon basin as a function of time, (2) the subsidence history of the margin, (3) the flexural response of the lithosphere to loading and unloading, and (4) the history of rift flank erosion.

\section{Methodology}

Our integrated approach to basin analysis incorporates both sequence stratigraphy and kinematic basin modeling to examine the first-order processes responsible for both the deformation of the lithosphere and the transport and deposition of sediments within the evolving basin. Iterating between the modeled time line stratigraphy and the observed stratal patterns allows us to establish a quantitative relationship between the tectonic deformation of the lithosphere and the formation 
of stratigraphic sequences and their bounding unconformities. Consequently, this combination provides a very powerful tool for predicting the structural and stratigraphic development of sedimentary basins and continental margins in response to compressional and extensional forces.

Sequence stratigraphy is the study of sediments and sedimentary rocks in terms of repetitively arranged facies and associated stratal geometry and makes use of the fact that sedimentary successions are pervaded by physical discontinuities [Sloss, 1988; Vail, 1987; Van Wagoner et al., 1990; Christie-Blick, 1991]. These physical discontinuities, which occur at a great range of scales, are generated by a number of different processes [ChristieBlick and Driscoll, 1995]. Common to virtually all of these discontinuities, independent of scale and origin, is that to a first approximation they separate older deposits from younger ones. The recognition of these discontinuities in the stratigraphic record is important because they allow the stratigraphic succession to be divided into geometrical units that have time-stratigraphic and genetic significance. Defining the stratal architecture, facies distribution and their spatial and temporal variability across continental margins is a necessary first step for determining where and when accommodation is created or destroyed along and across an evolving margin. The sequence stratigraphic approach does not actually require any assumptions about eustasy [Christie-Blick and Driscoll, 1995]; it is simply a tool to determine, layer by layer, how sedimentary successions are formed, from their smallest elements to the largest. Most importantly, we have established criteria that allow us to identify unconformities in the stratigraphic record that have a tectonic component [Driscoll et al., 1995].

The preserved stratal geometry and associated facies distribution in actively deforming regions can be used to distinguish between times of renewed tectonic activity and eustatic sea level changes alone [Driscoll and Hogg, 1995]. For example, the formation of unconformities in tectonically active basins, such as half graben and foreland basins, records subsidence in one portion of the basin that may be accompanied by contemporaneous tectonic uplift elsewhere [Christie-Blick and Driscoll, 1995; Driscoll et al., 1995]. As a result, unconformities can pass laterally from local subaerial unconformities into marine onlap surfaces. Deformational events followed by periods of tectonic quiescence are recorded in the stratigraphic record by marine onlapping packages that exhibit an overall shoaling upward trend as sediment infills the available space. However, the occurrence of tectonic deformation does not preclude the existence of contemporaneous eustatic sea level fluctuations. Consequently, sequence stratigraphic analysis allows us to ascertain the link between tectonic processes and the preserved stratigraphy. The Australian Geological Survey Organization (AGSO) 101 and 110, GECO-Prakla GPCT93, and Digicon 93BA series seismic reflection data as well as industry and Ocean Drilling Program (ODP) wells were used in this study to determine the tectonic and stratigraphic evolution of the Northern Carnarvon basin (Figure 1).

In recent years, there have been considerable advances in our understanding of lithospheric rifting and passive margin development [Braun and Beaumont, 1989; Weissel and Karner, 1989; Karner et al., 1998]. These conceptual models, following McKenzie [1978], also help to define the relationship between basin subsidence and heat input induced by lithospheric thinning. The recognition of low-angle normal faults by surface mapping has modified our conception of how extension is accommodated within the crust. The brittle collapse of the

\section{A. Initial Conditions}

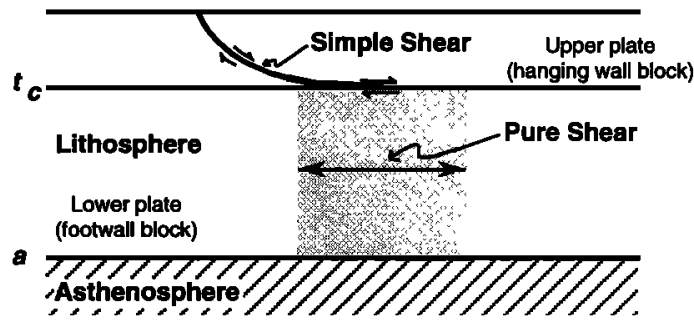

B. Kinematic Extension

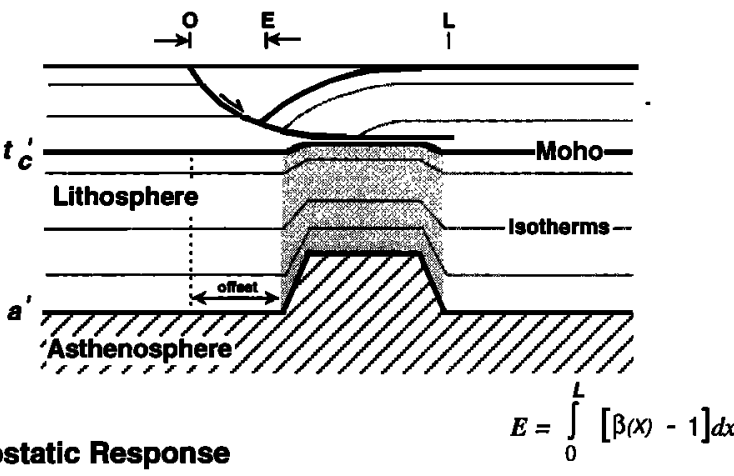

C. Isostatic Response
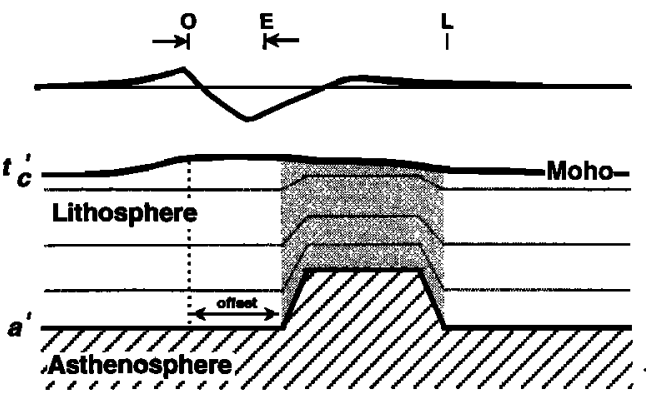

Figure 2. (a) Schematic representation of lithospheric extension by simple shear in the upper crust and balancing plastic (ductile) deformation in the lower crust/lithospheric mantle used to model the development of rift basins and flanking topography is shown. Slip along a border fault produces a topographic depression which is controlled by the heave $E$ across the fault and the shape of the fault (here drawn listric soling into the base of the crust). In this example, the balancing zone of lithospheric mantle extension is spatially offset and broader than the zone of crustal extension. The degree of lithospheric mantle extension critically controls the distribution and amount of heat added to the lithosphere during rifting. (b) The extension factor $\delta(x)$ can also be parameterized in terms of the amount of upper plate brittle deformation when the fault soles into a lower crustal weak zone with the lower crust and lithospheric mantle ductile deformation being described by $\beta(x)$. (c) The flexural adjustment of the lithosphere to crustal unloading and the input of heat to the base of the lithosphere is shown. The resultant shape of the rift basin is given by the summation of the kinematic depression and the total flexural rebound of the lithosphere.

upper crust in response to extension results in thinning of the crust that produces spatially discrete rift basins. Within the lower crust and lithospheric mantle, extension is accommodated by plastic (ductile) deformation. Referring to Figure 2, we can describe the response of the lithosphere to extension by considering the distribution and magnitude of the various ki- 
nematically produced loads [e.g., Weissel and Karner, 1989]. Starting with a prerift lithosphere of thickness $a$ and crustal thickness $t_{c}$, slip along the border fault produces a surficial hole by collapse of the hanging wall block (Figure 2). The heave across the fault, or equivalently the amount of extension, is $E$. After extension, the crustal and lithospheric thicknesses are $t_{c}^{\prime}$ and $a^{\prime}$, respectively. Thinning of the lithosphere mantle induces a thermal load represented by the passive rise of the lithosphere-asthenosphere boundary (Figure 2). The passive rise of this boundary introduces heat to the base of the thinned lithosphere. For convenience, we parameterize the degree of lithospheric thinning in terms of $\delta(x)$, the ratio of the prerift/ postrift crustal thickness, and $\beta(x)$ the ratio of the change in lithosphere mantle thickness. Note that while the cumulative extension represented by $\delta(x)$ and $\beta(x)$ must be balanced, their spatial distributions need not be related in a "one-to-one" fashion (the "offset" variable in Figure 2). The shape of the fault and where the fault soles are constrained by the seismic reflection and refraction data.

In Figure 2 we are explicitly assuming that the Moho is acting as a horizontal detachment. When this is not the case and the border fault soles into a weak zone within the lower crust, $\delta(x)$ is the extension factor for the upper plate and $\beta(x)$ is the extension factor for the lower plate. In such a scenario, $\beta(x)$ describes the extension within the lithospheric crust and mantle. These general definitions of $\delta(x)$ and $\beta(x)$ allow us to explore the isostatic effects of intracrustal detachments. In this paper, we use the following definition for detachment: a diffuse zone that separates (detaches) the brittle deformation in the upper crust from the ductile deformation in the lower crust and lithospheric mantle (e.g., strain partitioning [Driscoll and Karner, 1995]). We are not adopting the more restrictive definition of detachments proposed by Wernicke [1981] and subsequently modified and refined by Lister and Davies [1989] that defines detachments as narrow zones of relative movement which pass through the entire crust and/or lithosphere and are recorded by "mylonitic detachment terranes" (or metamorphic core complexes).

The kinematically created loads represented by the crustal "hole" and the input of heat to the base of the lithosphere (Figure 2) are readjusted by isostasy. For example, during rifting, the partial removal of the hanging wall block unloads the lithosphere, inducing an isostatic rebound. If flexural strength is maintained during extension, then this rebound will be regionally distributed with respect to the kinematically produced loads resulting in the formation of rift flanks. The same principles apply for transtensional systems (i.e., wrench tectonics) with the kinematically created loads recording the amount of extension across the fault associated with the transtensional deformation. Unless the strike-slip component of the deformation causes a change in lithospheric thickness, then there is no additional kinematically created load with this component of the deformation. The combination of the crustal hole with the isostatic rebound defines the general architecture of the rift basin (Figure 2). Following extension, the heat introduced to the base of the lithosphere during rifting dissipates, allowing the lithosphere to cool, contract, and subside. Thus the rapid subsidence that characterizes the rift phase is replaced by a slower form of subsidence associated with the conductive cooling of the rifted lithosphere. Consequently, basin formation in an extensional environment requires crustal thinning, either by extension or erosion. Lithospheric mantle thinning alone is not sufficient to generate a basin. Finally, rift and postrift sedimen- tation will tend to amplify any basin subsidence because it represents a positive load being added to the lithosphere.

The computer code used to investigate margin evolution is a two-dimensional (2-D) kinematic forward modeling program which tracks the thermal and mechanical response of the lithosphere both during and after rifting and thus the history of rift and postrift basin subsidence. Previous basin models have been limited to predicting the time line stratigraphy of the postrift section across passive continental margins [Royden and Keen, 1980; Watts et al., 1982; Kusznir et al., 1987]. This restriction was imposed because of the original assumption in the McKenzie [1978] lithospheric extension model in which rifting is treated as an instantaneous event (i.e., a thermally adiabatic process). Numerous finite rifting models have also been developed to examine the structural and thermal evolution of rift basins during extensional deformation [e.g., Cochran, 1983; Buck, 1988; Wang et al., 1989]. Nevertheless, in these applications the synrift stratigraphic architecture was neither predicted by or used as an input to the models. Our finite rift and rerift modeling procedure allows us to predict the architecture and stratigraphic development of rift basins as a function of space and time during extension. It was necessary to investigate this aspect because of the need to model the stratigraphy of the synrift formations and the thermal implications associated with multiple episodes of extensional deformation and migration of the deformation through time across and along the northwest Australian margin. Relevant input parameters to the kinematic and isostatic model for the Northern Carnarvon basin are summarized in Table 1 and modeled time lines and their tectonic significance are summarized in Table 2 . Initial crustal and lithospheric thicknesses were assumed to be 34 and $125 \mathrm{~km}$, respectively. These values were selected so that prior to extension the topography was isostatically balanced above sea level. While there is no direct evidence to support this assumption, the fluvial prerift sediments help to define a minimum crustal thickness. Furthermore, low-relief topography and a lithospheric thickness approaching equilibrium (i.e., $125 \mathrm{~km}$ ) are consistent with the large time span since the last orogenic event to affect the region (340 Ma, Carboniferous Alice Springs orogeny [Warris, 1993]). Porosity characteristics are input as a function of position across the margin, which are based on industry and ODP well $\log$ data (Figure 1). The process of erosion is also treated as an exponential function that defines the destruction of topography in terms of a "half-life." Subaerial erosion is regarded as a function of height (i.e., highest topography is eroded quickest). The assumptions dictating subaerial erosion serve only to approximate process. We are concerned with the longevity of the rift flank topography rather than the details of how it is eroded.

\section{Tectonic and Stratigraphic Evolution}

In this section, we present stratigraphic evidence documenting the timing and spatial distribution of where and when accommodation was created or destroyed across the Northern Carnarvon basin. These observations, taken together with the results from the kinematic and isostatic basin modeling, allow us to determine the tectonic significance of the preserved stratigraphy across and along the basin. Seismic lines AGSO 110-12 and Digicon 93BA-93 are an east-west profile across the Peedamullah Shelf, Barrow subbasin, Alpha Arch, Exmouth subbasin, and Exmouth Plateau (Figure 1 and Plate 1). The Exmouth subbasin is delineated by the Alpha Arch to the east 
Table 1. Modeling Parameters for Northern Carnarvon Basin

\begin{tabular}{|c|c|c|}
\hline Parameter & Description & Value \\
\hline$x, z$ & horizontal and vertical coordinates & \\
\hline$t$ & time since rifting/rerifting event & \\
\hline$\Delta t_{\text {rift }}$ & finite rifting interval & $5-20 \mathrm{Myr}$ \\
\hline$\delta(x)$ & $\begin{array}{l}\text { upper plate extension factor } \\
\text { lower plate thinning factor }\end{array}$ & \\
\hline $\begin{array}{l}\beta(x) \\
\delta,(x)\end{array}$ & & \\
\hline $\begin{array}{l}\delta_{l}(x) \\
\beta_{l}(x)\end{array}$ & $\begin{array}{l}\text { upper plate compression (inversion) factor } \\
\text { lower plate compression (inversion) factor }\end{array}$ & \\
\hline$T(x, z, t)$ & lithospheric temperature structure & \\
\hline$T_{m}$ & asthenosphere temperature & $1333^{\circ} \mathrm{C}$ \\
\hline$\alpha$ & thermal expansion coefficient & $3.28 \times 10^{-5} \mathrm{~K}^{-1}$ \\
\hline$\kappa$ & thermal diffusivity & $8 \times 10^{-7} \mathrm{~m}^{2} \mathrm{~s}^{-1}$ \\
\hline$C_{p}$ & specific heat & $1.05 \mathrm{~J} \mathrm{~g}^{-1} \mathrm{~K}^{-1}$ \\
\hline$q_{0}$ & background heat flow & $42 \mathrm{~mW} \mathrm{~m}^{-2}$ \\
\hline $\begin{array}{l}t_{c} \\
t^{\prime}\end{array}$ & prerift crustal thickness & $34 \mathrm{~km}$ \\
\hline $\begin{array}{l}t_{c}^{\prime} \\
t_{d}(x)\end{array}$ & postrift crustal thickness & \\
\hline $\begin{array}{l}t_{d}(x) \\
t_{c}^{\prime}\end{array}$ & $\begin{array}{l}\text { intracrustal detachment geometry } \\
\text { asymptotic limit of crustal detachment }\end{array}$ & \\
\hline$a$ & equilibrium lithospheric thickness & $125 \mathrm{~km}$ \\
\hline$a^{\prime}$ & postrift lithospheric thickness & \\
\hline$\rho_{a}$ & density of asthenosphere at $0^{\circ} \mathrm{C}$ & $3330 \mathrm{~kg} \mathrm{~m}^{-3}$ \\
\hline$\rho_{a}^{\prime}$ & density of asthenosphere at $T_{m}$ & $3179 \mathrm{~kg} \mathrm{~m}^{-3}$ \\
\hline $\begin{array}{l}\rho_{c} \\
\rho_{s}(z)\end{array}$ & $\begin{array}{l}\text { density of crust at } 0^{\circ} \mathrm{C} \\
\text { sediment density }\end{array}$ & $2800 \mathrm{~kg} \mathrm{~m}^{-3}$ \\
\hline$\rho_{a}$ & sediment grain density & $2650 \mathrm{~kg} \mathrm{~m}^{-3}$ \\
\hline$\Phi(z)$ & bulk sediment porosity & $\Phi_{0} e^{-k_{p z}}$ \\
\hline$\Phi_{0}$ & surface porosity & $60 \%$ \\
\hline & porosity decay constant & $2.5 \mathrm{~km}$ \\
\hline$D(x, t)$ & lithospheric rigidity & $E T_{e}(x, t) / 12\left(1-v^{2}\right)$ \\
\hline$T_{e}(x, t)$ & effective elastic thickness & \\
\hline$v$ & Poisson's ratio & 0.25 \\
\hline$E$ & Young's modulus & $6.5 \times 10^{10} \mathrm{~Pa}$ \\
\hline$g$ & gravitational acceleration & $9.82 \mathrm{~m} \mathrm{~s}^{-2}$ \\
\hline & controlling isotherm for $T_{e}$ & $450^{\circ} \mathrm{C}$ \\
\hline$h(x, t)$ & topographic relief & \\
\hline $\begin{array}{l}\Delta h(x, t) \\
k_{e}^{-1}\end{array}$ & $\begin{array}{l}\text { topographic load removed by erosion } \\
\text { erosional time constant }\end{array}$ & \\
\hline & crust & $82 \mathrm{Myr}$ \\
\hline & sediment & $10-40 \mathrm{Myr}$ \\
\hline$\Delta S_{L}$ & maximum first-order eustatic sea level variation & $200 \mathrm{~m}$ \\
\hline
\end{tabular}

Table 2. Modeled Time Lines and Their Tectonic Significance

\begin{tabular}{rccll}
\hline $\begin{array}{c}\text { Time } \\
\text { Line }\end{array}$ & $\begin{array}{c}\text { Geological } \\
\text { Age, Ma }\end{array}$ & $\begin{array}{c}\text { Time Since Basin } \\
\text { Initiation, Myr }\end{array}$ & Geological Formation* & Process \\
\hline 1 & 253 & 0 & Locker Shale & rifting 1 \\
2 & 233 & 20 & Mungaroo sands & postrift 1 \\
3 & 228 & 25 & lower Dingo clay stone & rifting 2 \\
4 & 215 & 38 & & \\
5 & 210 & 43 & & \\
6 & 209 & 44 & & \\
7 & 200 & 53 & & \\
8 & 194 & 59 & upper Dingo clay stone & rifting 3 \\
9 & 188 & 65 & & \\
10 & 181 & 72 & Dupuy sands & postrift 3 \\
11 & 175 & 78 & Barrow Group & \\
12 & 169 & 84 & Muderong shale & \\
13 & 155 & 98 & upper Gearle siltstone & postrift 4 \\
14 & 150 & 103 & upper Gearle siltstone & postrift 4 \\
15 & 144 & 109 & Trealla limestone & postrift 4 \\
16 & 134 & 119 & (Cape Range Group) & \\
17 & 125 & 128 & 162 & \\
18 & 91 & 238 & 253 &
\end{tabular}

*Time lines define the approximate base of the geological formations. 

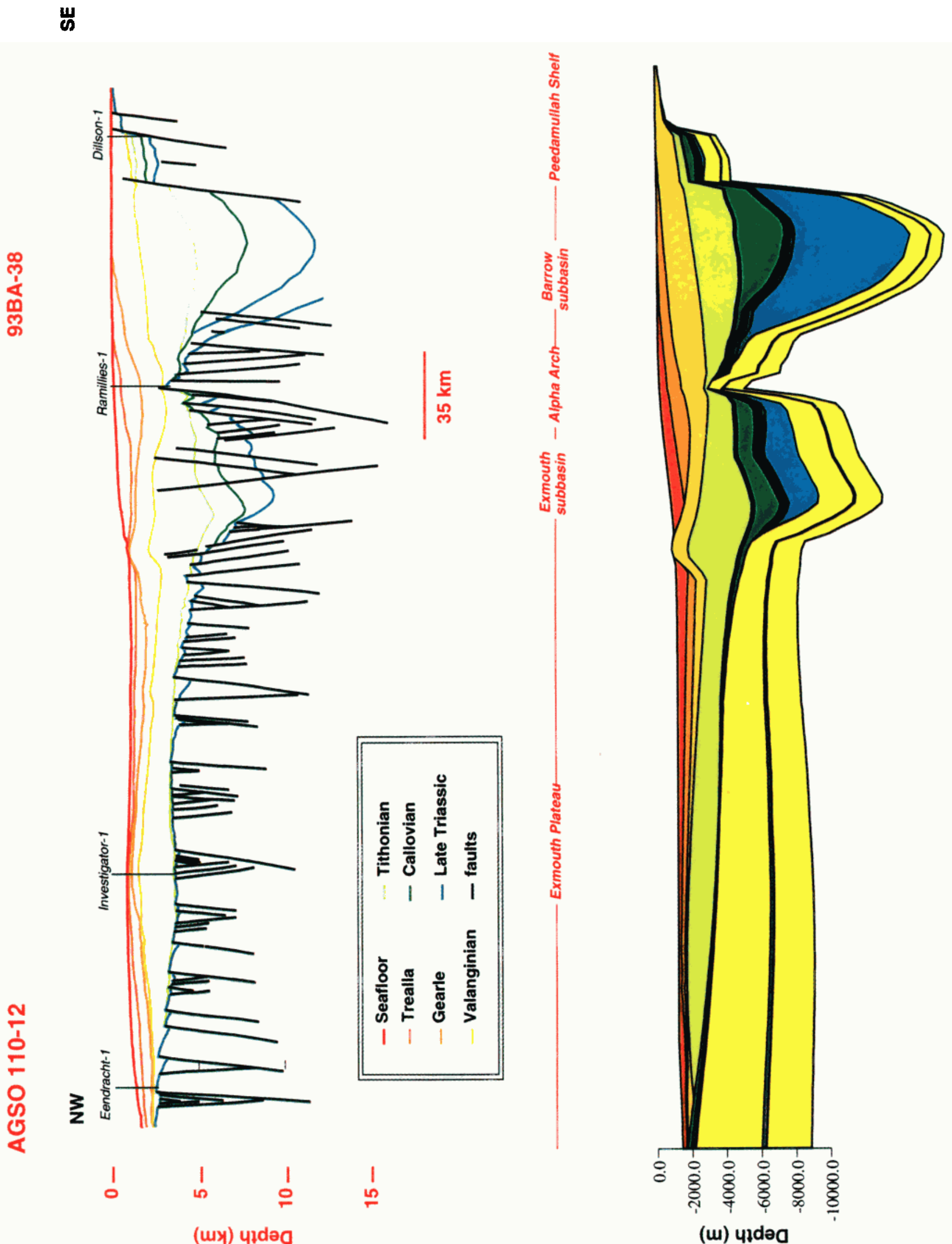

(iv) uldeg 


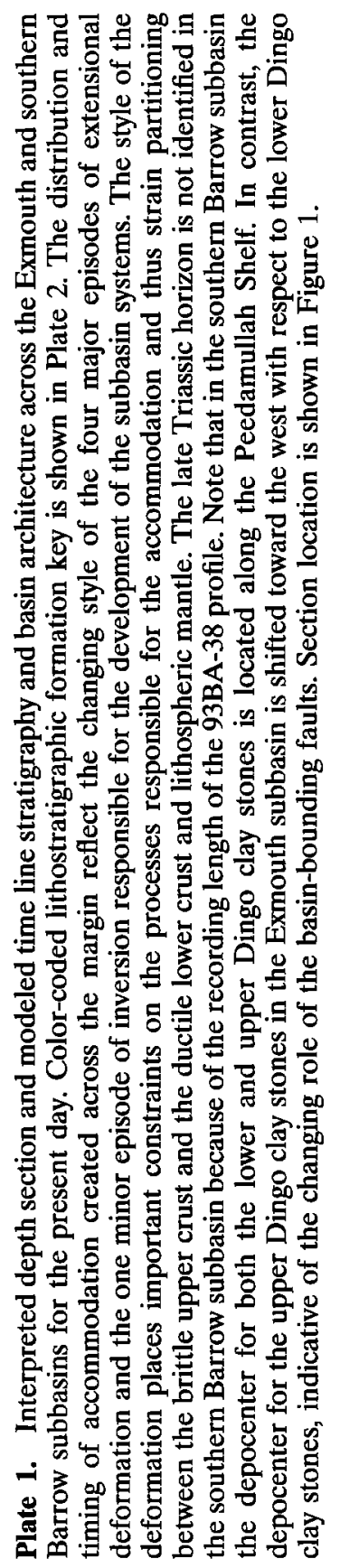

and the Exmouth Plateau to the west. The northern extent of the Exmouth subbasin overlaps with the southern portion of the Barrow subbasin, and the termination of these basins is controlled by major accommodation zones. The southern Barrow subbasin is bounded to the east by the Peedamullah Shelf and to the west by the Alpha Arch and its southern equivalents (Figure 1).

\subsection{Late Permian Extension}

The basal member of the Triassic, the Locker Shale, is a transgressive marine deposit resting unconformably on Paleozoic sediments [Kopsen and McGann, 1985] (Figure 3). The Locker shale passes upward into the Mungaroo formation, which is a deltaic system that grades vertically into a thick unit of stacked fluvial channel deposits [Barber, 1982; Exon et al., 1992] (Figure 3). The overall thickness of the Triassic section systematically increases toward the west with the depocenter occurring along the western edge of the Northern Carnarvon basin [Cockbain, 1989]. Minor lateral thickness variations of the Locker and Mungaroo formations are observed across the Rankin Platform and the Peedamullah Shelf (Plate 1). The Mungaroo formation is capped by a thin transgressive succession of nearshore and shelf fine-grained clastics and carbonates of Hettangian-Sinemurian age. This marine transgression occurred in a general southeasterly direction. The great thickness of fluvio-deltaic deposits $(\sim 3000 \mathrm{~m})$ indicates that basin subsidence across the region was occurring during most of the middle to late Triassic.

\subsection{Model Predictions for Late Permian Extension}

Prior to examining the tectonic and stratigraphic development for any given time interval, it is necessary first to model the entire stratigraphic succession of the Northern Carnarvon basin because the preserved stratigraphy records the total history of margin development. By forward modeling the thickness, stratal geometry, and paleowater depths across the Northern Carnarvon basin (Plates 1 and 2), we are then able to use the model predictions to examine the tectonic and stratigraphic development of the margin for any given time interval (Figure 4). Note the close correlation between the depth sections across the Barrow and Exmouth subbasin, the Alpha Arch, and the Exmouth Plateau and the modeled development of the region (Plate 1 ).

The distribution and thickness of the synrift Triassic Locker Shale and the postrift Mungaroo formation across the margin are a direct consequence of the distribution and magnitude of late Permian rifting (Figure 4). To model the thickness and distribution of the Locker formation requires broadly distributed, depth-independent extension (i.e., $\delta(x)=\beta(x)$ ) across the region at this time (Plate 2 and Figure 4). A consequence of depth-independent extension is that accommodation is generated at the time of rifting. Conversely, depth-dependent extension can result in negligible accommodation during rifting with large amounts of subsidence in the postrift phase. The Permian extension increased toward the west, with a maximum value of 1.5 (Figure 4). Matching the present-day distribution and thickness of the Permo-Triassic sequences across the Peedamullah Shelf constrains the spatial extent and magnitude of the late Permian extension. For example, if we expand the lateral distribution of Permian extension farther toward the east, then substantial thicknesses of Permo-Triassic sediments are predicted to occur across the region of the high-standing Peedamullah Shelf, contrary to observations (Plates 1 and 2). 


\section{Carnarvon Basin - Southern Transect}

A.
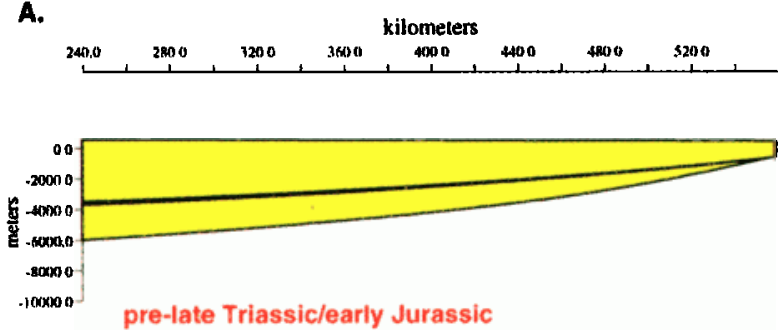

B.

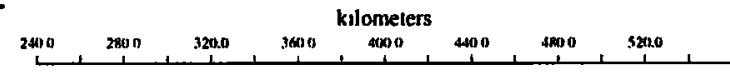

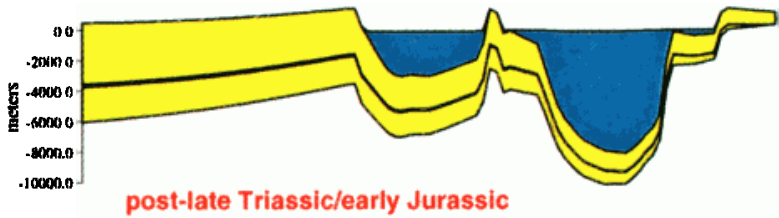

c.
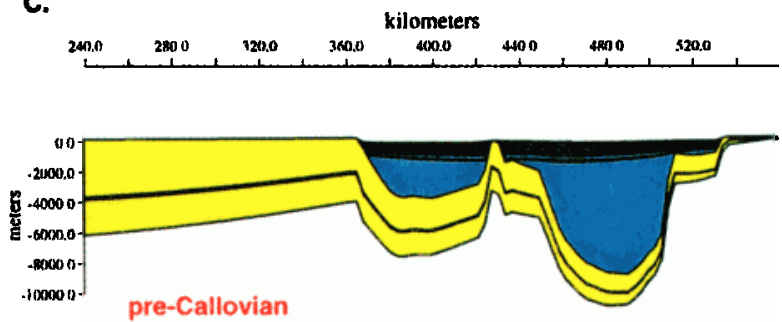

D.

\begin{tabular}{|c|c|c|c|c|c|c|c|}
\hline 2400 & 2800 & 322,0 & 3600 & kilometers & $\$ 00$ & 4Ray & 5200 \\
\hline
\end{tabular}

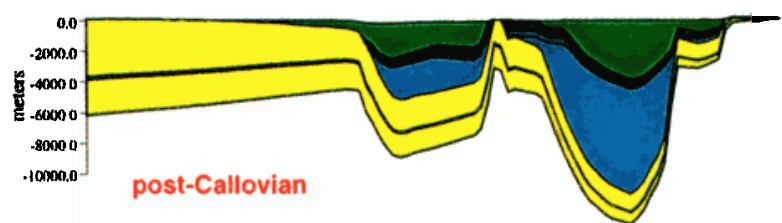

E.
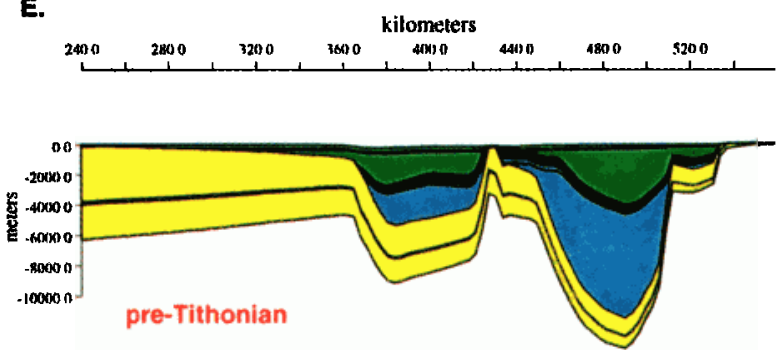

F.
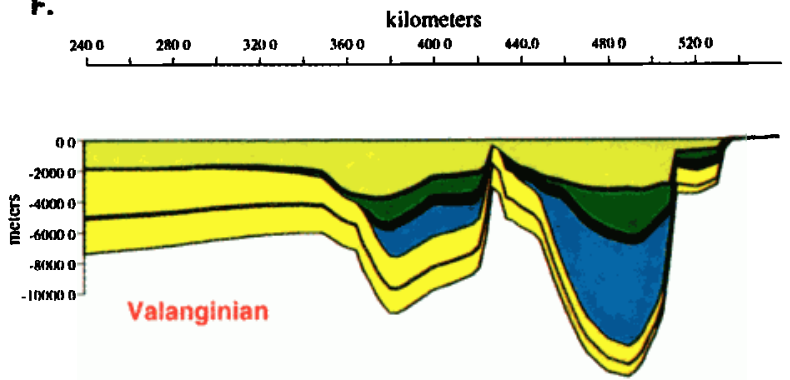

G.
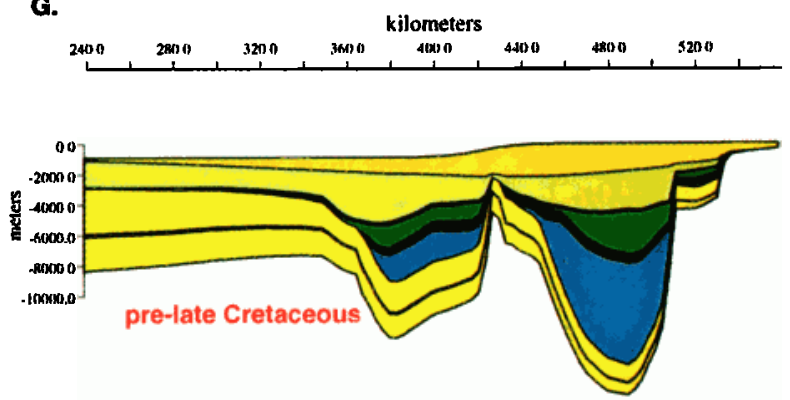

H.
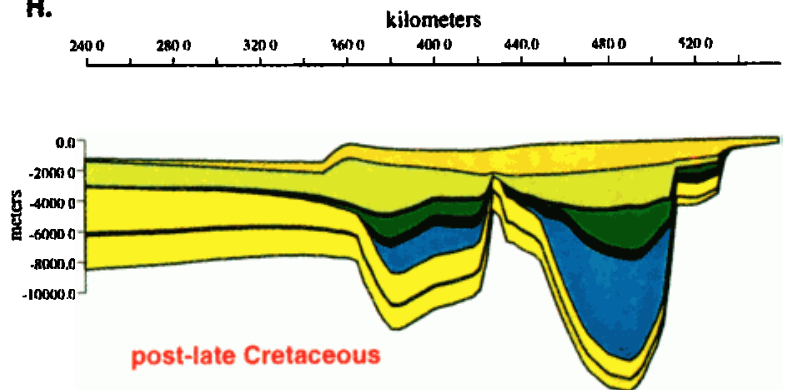

I.
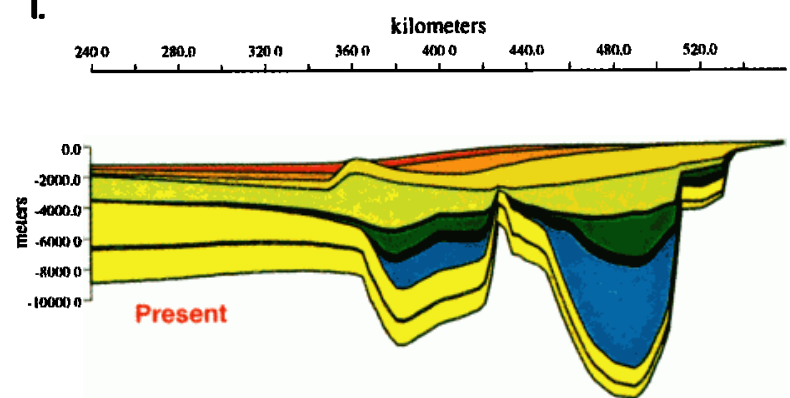

$\square$

Locker Shale

upper Dingo Fm

Ladinian-Carnian

Barrow Group

Mungaroo Sands

upper \& lower Gearle

lower Dingo Fm

Pahogene Sequences

upper Dingo Fm 
The subsidence history across the Exmouth Plateau also constrains the magnitude of the late Permian extension. Increasing the amount of Permian extension across the region increases the amplitude of the thermal subsidence. If we assume too large a value for the Permian extension, then significant accommodation is generated across the margin during Jurassic time. The observed localized Jurassic depocenters suggest that the accommodation was generated predominantly by restricted brittle (i.e., fault induced) deformation rather than by regional thermal subsidence associated with the late Permian extensional event (Plate 2).

\subsection{Late Triassic Extension}

Continental siliciclastics at the end of the Triassic supercycle (e.g., orogenic collapse) contrast with the marine and marginal-marine siliciclastics of the lower and upper Jurassic supercycles (i.e., rift phases 2 and 3; Figure 3). The rapid formation of accommodation recorded by the abrupt transition from progradational fluvial-deltaic clastics of the Mungaroo formation to the open marine silts and clays of the lower Dingo clay stone within the Barrow and Dampier subbasin marks the onset of renewed extension beginning in Rhaetian time (Figure 3) [Kopsen and McGann, 1985; Veenstra, 1985; Boote and Kirk, 1989].

The divergence and rotation of seismic reflectors above the Norian unconformity in the Northern Carnarvon basin are indicative of differential subsidence and block rotation (Plate 3). The depocenter for the lower and middle Dingo clay stones is located in the Barrow, Dampier, and Exmouth subbasins (Figure 1) [Boote and Kirk, 1989]. We have developed a defendable criterion to define the boundary between the Mungaroo formation and the overlying lower Dingo clay stones within the depocenters by recognizing that the Locker Shale and Mungaroo formation are regionally developed with only minor lateral thickness variations and the lower Dingo clay stones are locally developed with large lateral thickness variations (Plates 1 and 2). The first package of seismic reflectors that diverge and onlap onto the underlying parallel and roughly concordant reflectors records the boundary between the top of the Mungaroo formation and the base of the lower

Plate 2. (opposite) Predicted time line stratigraphy and basin architecture across the Northern Carnarvon basin (Exmouth and southern Barrow subbasins) from the Permian to Present based on the model. The horizontal scale for the modeled basin cross sections is relative, although the origin $(x=0$ $\mathrm{km}$ ) represents the position of the ocean-continent boundary. The western position corresponds to the Exmouth Plateau, and the eastern position corresponds to the Peedamullah Shelf. Basin cross sections are presented for (a) pre-late Triassic/ early Jurassic (Rhaetian, $\sim 215 \mathrm{Ma}$ ) showing the distribution of the Locker and Mungaroo formations at the end of late Permian extension, (b) post-late Triassic/early Jurassic (Hettangian, $208 \mathrm{Ma}$ ), following the Rhaetian extension, (c) preCallovian (Bathonian, $\sim 175 \mathrm{Ma}$ ), prior to the Callovian extension, (d) post-Callovian (Oxfordian, 155 Ma), after the Callovian extension, (e) pre-Tithonian (Kimmeridgian, $\sim 150$ $\mathrm{Ma}$, prior to the onset of Tithonian-Valanginian extension and deposition of the Barrow group, (f) Valanginian ( 134 $\mathrm{Ma}$ ), after the Tithonian-Valanginian rifting, (g) pre-late Cretaceous (Barremian, $\sim 125 \mathrm{Ma}$ ), prior to the Turonian inversion, (h) post-late Cretaceous (Turonian, $91 \mathrm{Ma}$ ), after Turonian inversion, and (i) the Present margin configuration.
Dingo formation. Along the structural highs, well data corroborate our interpretation (Plates 1 and 2).

The late Triassic to Callovian interval thickens toward the east in both the Exmouth and southern Barrow subbasins (Plate 2). The observed thickness variations suggest that the basin bounding fault for the Exmouth subbasin was located along the western flank of the Alpha Arch and for the southern Barrow subbasin the border fault was located along the western edge of the Peedamullah Shelf (Plate 1). The consequent footwall uplift of the Alpha Arch and Peedamullah Shelf during the second phase of deformation, which commenced in late Triassic to early Jurassic time (Figure 3 ) affected the drainage networks across the shelf and thus limited the access of fluvial systems into the rift basin proper.

\subsection{Model Predictions for Late Triassic Extension}

The renewed episode of extension in the late Norian/ Rhaetian affected the northwest Australian margin, generating an extensive along-strike network of basins (Figure 1). The extension was limited to a narrow portion of the margin producing the Barrow, Dampier, and Exmouth subbasins and the Gascoyne and Cuvier rift basins (Figure 1). Even though the basins and subbasins were narrow and localized, their location along the edge of the Peedamullah Shelf and the western edge of the Exmouth Plateau made them efficient traps for clastic sediment derived from the Australian continent to the east and the Greater Indian continent to the west. Consequently, thick synrift depositional wedges were confined within the structurally controlled topography of these evolving basins, thereby starving the Exmouth Plateau and Alpha Arch of clastic sediment (Plate 2) [Exon et al., 1992; Haq et al., 1992]. In addition to the extensional deformation being spatially limited, model results indicate that the brittle and ductile extension was depthindependent with a maximum value of 1.46 (i.e., $\delta=\beta$, Figure 4).

The Flinders fault zone, located along the western edge of the Peedamullah Shelf, was the basin-bounding fault system to Rhaetian extension with the southern Barrow subbasin being the hanging wall block and the Peedamullah Shelf being the footwall block (Plates 1 and 2). Rift-induced flexural uplift of the Peedamullah Shelf and its consequent erosion removed a large section of the underlying Mungaroo formation (Plate 2). At Dillson-1 well, the Mungaroo formation and Locker Shale were not eroded because the well is located on a downdropped block that effectively competed with the rift-induced footwall uplift (Plate 2). Our modeling results suggest that the Alpha Arch, which delineates the western boundary of the southern Barrow subbasin and the eastern boundary of the Exmouth subbasin (Figure 1), represents both the collapsed hanging wall to the Flinders Fault and the uplifted footwall to the faults immediately west of the Alpha Arch at this time (Plate 2). Ramillies-1 well, located on the crest of the Alpha Arch, recovered the upper Mungaroo formation, indicating that only minor erosion has occurred across the arch. This is consistent with the tectonic history of the Alpha Arch, that is, the hanging wall to the extensional deformation in the east and the footwall to the deformation in the west. The eastern edge of the Exmouth Plateau also experienced uplift due to extensional unloading even though it was the hanging wall block to the late Triassic extension. This uplift occurred because the wavelength of the basin was narrow with respect to the flexural wavelength of the lithosphere $(\lambda=60-80 \mathrm{~km})$ and the series of antithetic faults caused minor extensional unloading (Plate 1). Minor faulting across the Exmouth Plateau accompanied the Rhae- 


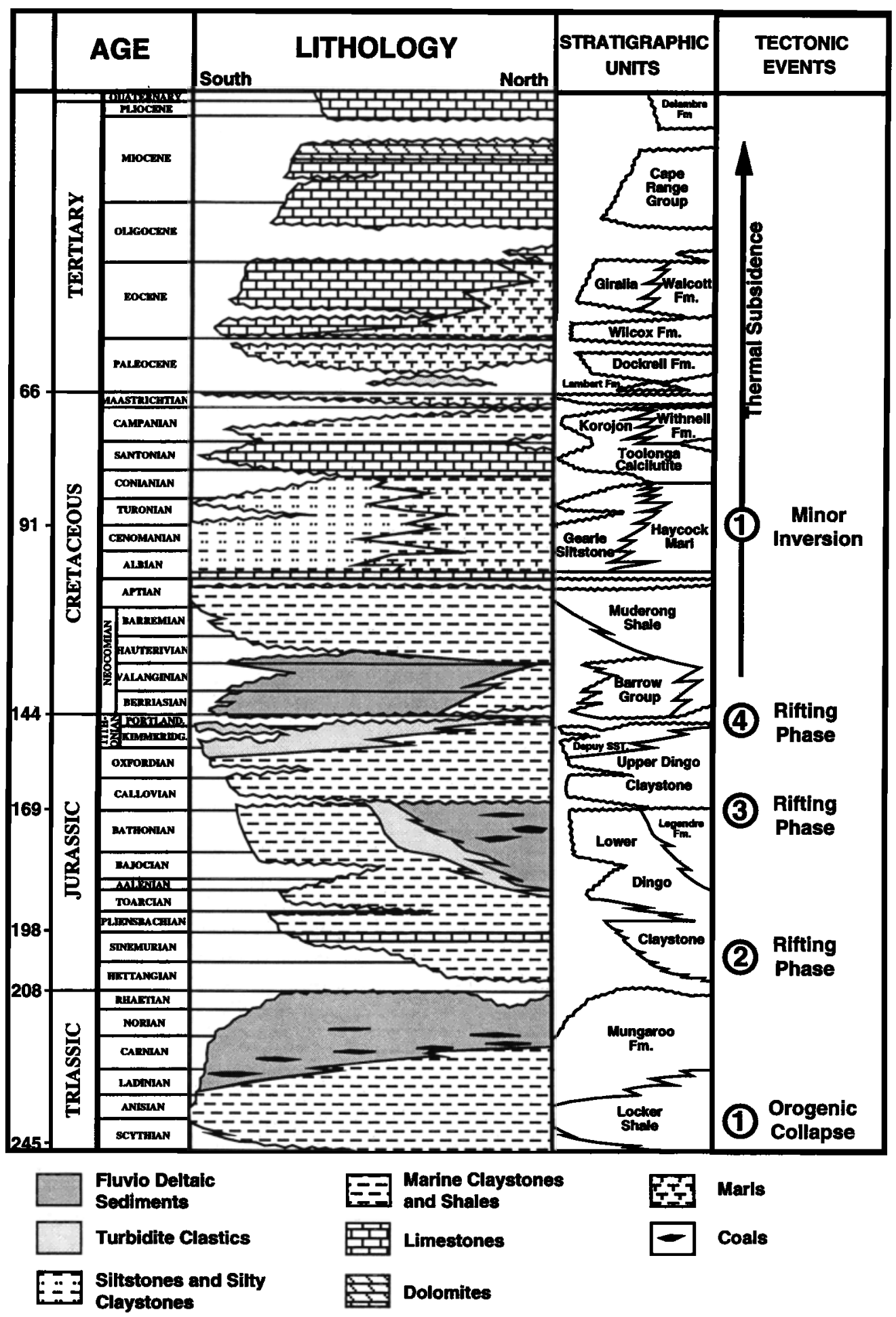

Figure 3. Generalized Mesozoic and Tertiary chronostratigraphy for the northwest Australian margin that builds upon previous work along the margin [e.g., Kopsen and McGann, 1985; Boote and Kirk, 1989; Cockbain, 1989; Kopsen, 1994]. The tectonostratigraphic chart illustrates the relationship between extensional events across the margin and the stratigraphic packages. Four major episodes of extensional deformation and one minor inversion event affected the northwest Australian margin: (1) Late Permian extension and orogenic collapse, (2) Rhaetian extension associated with rift onset in the Argo basin, (3) Callovian extension generating the onset of seafloor spreading in the Argo basin (marine magnetic anomaly M25), (4) Tithonian to Valanginian extension associated with rifting and the onset of seafloor spreading in the Gascoyne and Cuvier basins (marine magnetic anomaly M10) (note that the base of each tectonic megasequences is defined by a flooding surface and marine onlap within the depocenter), and (5) reorganization of the Indo-Australian plates roughly synchronous with the Turonian (Gearle horizon) minor reactivation of fault systems within the Exmouth, Barrow, and Dampier subbasins. 

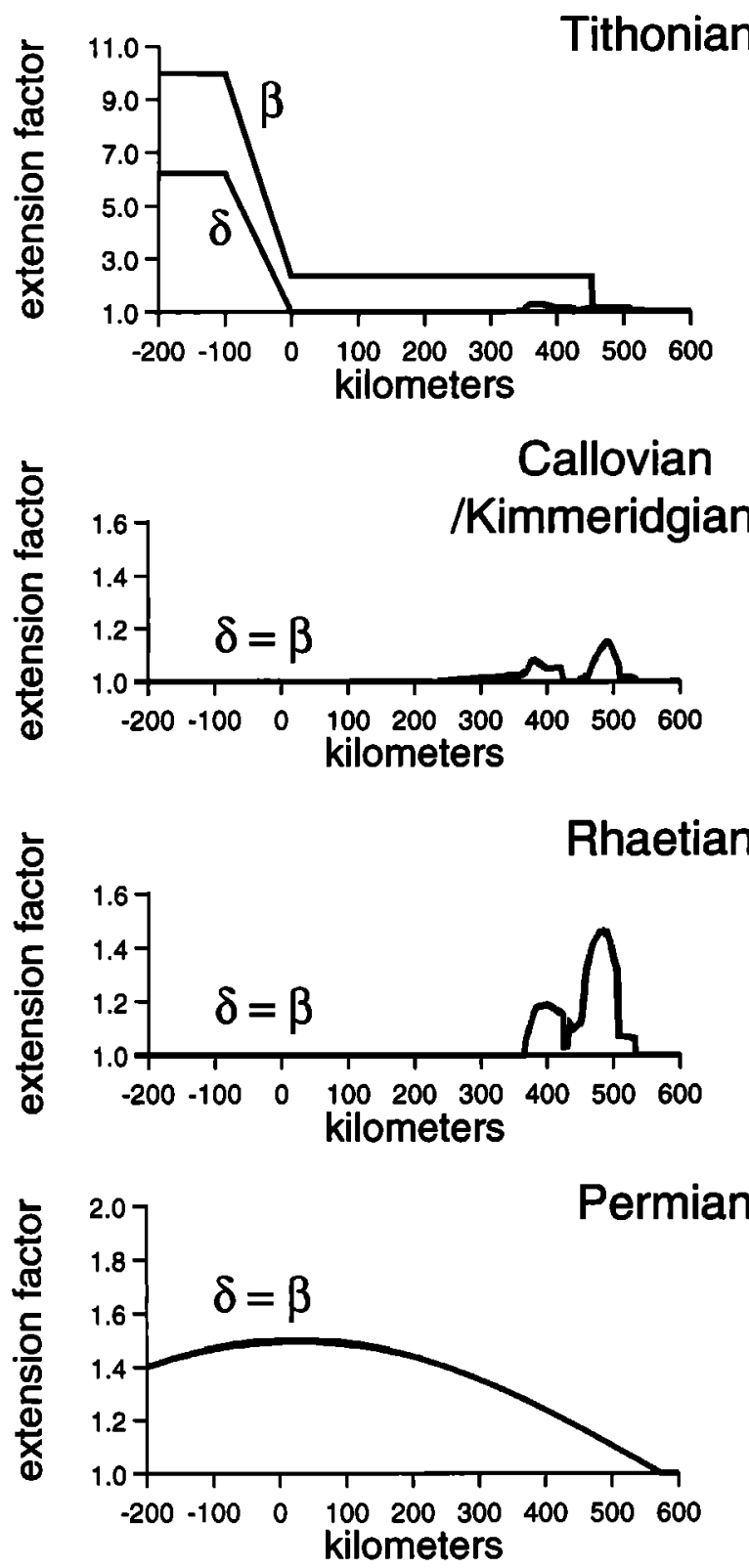

Figure 4. Distribution, magnitude, and timing of extension necessary to reproduce the general basin architecture and preserved stratigraphy of the basins composing the Carnarvon Basin. The amount of crustal thinning determines the distribution of rift-phase subsidence. In turn, crustal thinning is a combination of the degree of upper plate thinning, defined by $\delta$, and the degree of lower plate thinning, defined by $\beta$. Intracrustal detachments determine the geometry of the upper and lower plates. The $\beta$ function also defines the degree of lithospheric mantle thinning and critically determines the amount of thermal uplift and heat input into the lithosphere during rifting and the amplitude and distribution of postrift subsidence. The distribution, magnitude, and timing of extension for the Permian, Triassic, Callovian, and Tithonian rifting events are shown for the Exmouth and southern Barrow subbasins.

tian development of the Exmouth and southern Barrow subbasins (Plates 1 and 3).

\subsection{Callovian Extension}

Two Mesozoic tectonic events resulted in the formation of oceanic crust; the Callovian event that generated oceanic crust within the Argo Abyssal Plain (marine magnetic anomaly M25, $\sim 163 \mathrm{Ma}$ ), and the Tithonian-Valanginian event, which generated oceanic crust within the Gascoyne and Cuvier Abyssal Plains (marine magnetic anomaly M10, 132 Ma). These events document the complete continental rupturing and separation of northwest Australia from Greater India and related continental fragments [Boote and Kirk, 1989]. The Callovian extensional episode, which correlates with the onset of seafloor spreading in the Argo Abyssal Plain, reactivated the border fault systems that delineate the Barrow and Exmouth subbasins. Similar to the late Triassic event, only minor faulting across the Exmouth Plateau accompanied the Callovian reactivation of the subbasins (Plates 1 and 3). The upper Dingo clay stone, which is preserved in the Barrow, Exmouth, and Dampier subbasins, records this episode of fault reactivation associated with the Callovian extension (Figure 3) [Veenstra, 1985; Kopsen and McGann, 1985; Boote and Kirk, 1989]. The upper Dingo clay stone is a thick succession of silty clay stone deposited below wave base (water depths of approximately hundreds of meters or greater).

Along the Peedamullah Shelf, the initial prodelta shales of the upper Dingo clay stone were eventually replaced by the Dupuy sands, which are associated with prograding deltas and turbidites (Figure 3). The east-to-west progradation of the Dupuy sands implies that paleo-water depths existed within the Barrow subbasin adjacent to the Alpha Arch and most likely in the Exmouth subbasin. The amplitude of the clinoforms observed in the seismic reflection data indicates that minimum water depths at this time were of the order of $\sim 200 \mathrm{~m}$ [Tait, 1985; Boote and Kirk, 1989].

\subsection{Model Predictions for Callovian Extension}

The Callovian extensional episode, which correlates with the onset of seafloor spreading in the Argo Abyssal Plain, reactivated the border fault systems that delineated the Exmouth and southern Barrow subbasins with only minor accompanying deformation across the Exmouth Plateau (Plates 1 and 2). Similar to the Rhaetian event, the Callovian phase of extension was depth-independent with a maximum extension factor of 1.15 (i.e., $\delta=\beta$, Figure 4). Furthermore, the active fault system for the southern Barrow subbasin remained along the eastern edge of the basin (Plate 2). The extensional unloading and consequent footwall uplift of the Peedamullah Shelf tended to divert river systems away from the southern Barrow subbasin.

Within the Exmouth subbasin the dominant border fault system appears to have switched from along the western edge of the Alpha Arch (late Triassic extension) to the eastern edge of the Exmouth Plateau (middle Jurassic extension, Plates 1 and 2). However, because the extensional deformation was distributed along the eastem edge of the Exmouth Plateau, the uplift due to extensional unloading was counteracted by crustal thinning (Plate 2), thus explaining the accommodation created at this time. The alternating footwall/hanging wall block role of the Exmouth Plateau is suggested by the westward migration of the depocenter through time in the Exmouth subbasin (Plate 1).

\subsection{Tithonian Extension}

During Tithonian-Valanginian time, the continental lithosphere along the western boundary of the Exmouth Plateau and the southwestern Australian margin was breached and oceanic lithosphere was emplaced (marine magnetic anomaly M10 [Boote and Kirk, 1989]). Minor fault reactivation occurred within the Barrow, Exmouth, and Dampier subbasins as well as 


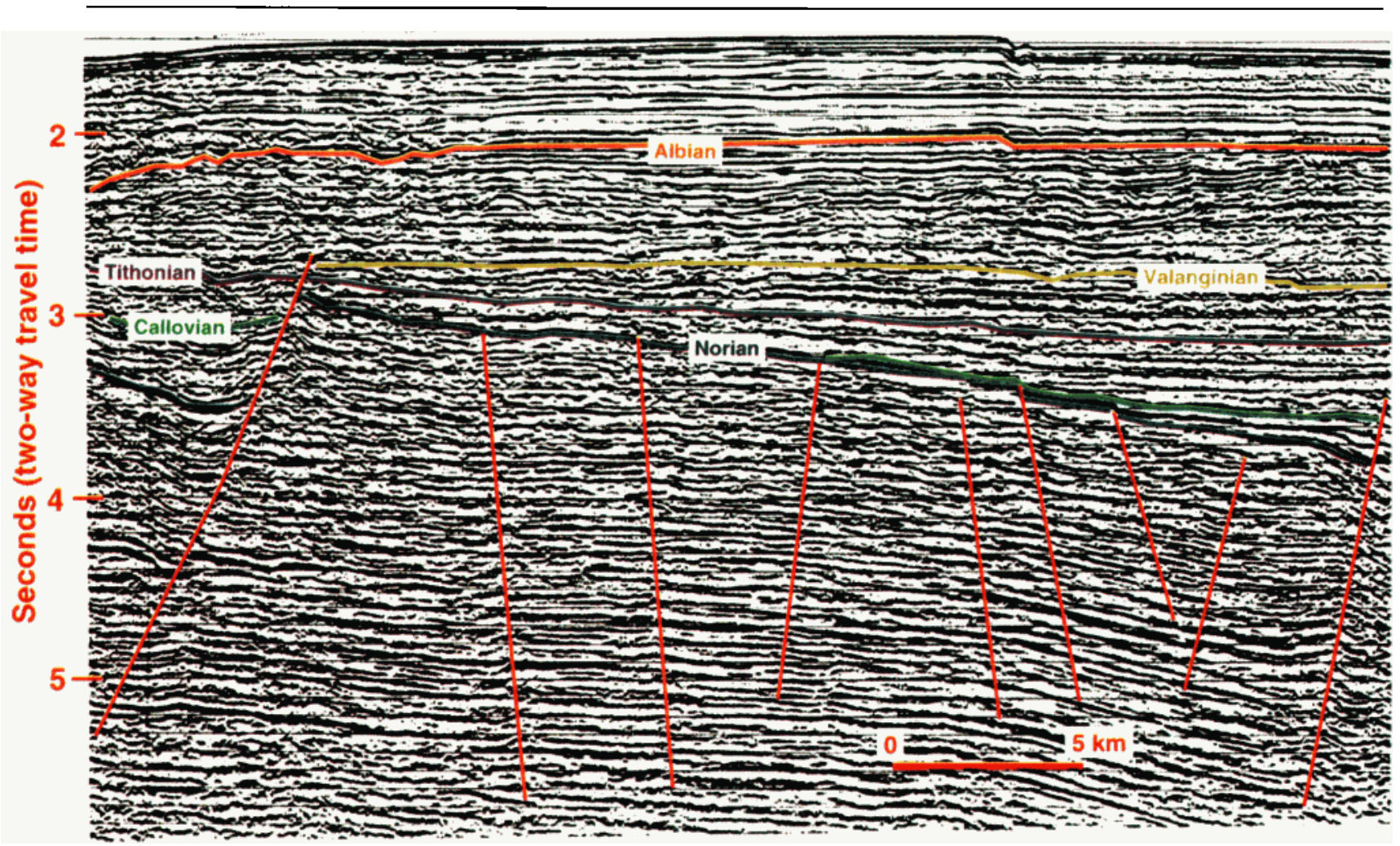

Plate 3. An enlarged portion of an AGSO multichannel seismic reflection profile across the Exmouth

Plateau, located just north of line AGSO 110-12, illustrating the minor erosional truncation beneath the Tithonian unconformity. The truncation associated with this unconformity is observed across most of the region, suggesting that large portions of the Exmouth Plateau were emergent or at very shallow water depths prior to the deposition of the Barrow delta. The tope of the Barrow succession is marked by the Valanginian unconformity.

the Exmouth Plateau (Plates 1 and 2). AGSO seismic reflection profiles across the Exmouth Plateau imaged a Tithonian angular unconformity that records minor truncation of the underlying Mesozoic stratigraphic successions (Plate 3). This truncation is observed across most of the region, suggesting that large portions of the plateau were emergent or at very shallow water depths prior to the deposition of the Barrow delta. A broad shallow water environment across large portions of the platform is also consistent with facies analysis of the Barrow delta sediments [Erskine and Vail, 1988; Tait, 1985]. Paleo-water depth estimates for the Valanginian together with the present-day bathymetry and thickness of the late Cretaceous and Tertiary stratigraphic sequences (Plates 1 and 2) indicate that significant subsidence occurred across the Northern Carnarvon basin since Valanginian time. In contrast to the localized accommodation associated with the lower and upper Dingo clay stones, the post-Valanginian accommodation appears to be regionally distributed and increases toward the west (i.e., toward the ocean-continent boundary). There is only minor Tithonian to Valanginian brittle deformation across the Exmouth Plateau (Plates 1-3). Note that the post-Valanginian accommodation has been amplified along the eastern margin by sediment loading (Plate 2) and, taken together with the long-wavelength subsidence that increases toward the west, has resulted in an overall arching of the margin (Figure 5). Thus we have an interesting paradox where regional postrift subsi- dence is associated with only minor amounts of upper crustal brittle deformation during the Tithonian-Valanginian extensional event (Plate 2).

Reflector geometries observed in the seismic data indicate the following: (1) the accommodation generated by brittle deformation in Tithonian time across the Northern Carnarvon basin was localized and its magnitude was minor in comparison to the regional subsidence, (2) the truncation associated with the Tithonian unconformity is minimal, and (3) the Tithonian to Valanginian sequence thins predominantly by onlap onto structural highs (Plate 3 ). These observations are the critical constraints requiring large broadly distributed extension across the Exmouth Plateau to accommodate the Barrow delta sediments, the general arching of the Exmouth Plateau, and the large post-Valanginian subsidence required to explain both the present-day water depths and postrift sediment thicknesses observed across the Northern Carnarvon basin.

\subsection{Model Predictions for Tithonian Extension}

Clearly, the regional distribution and amplitude of the postValanginian subsidence is not consistent with the minor amounts of Tithonian-Valanginian brittle crustal extension observed across the Northern Carnarvon basin (Plate 2). The form, distribution, and longevity of this subsidence phase are characteristic of the cooling and contraction of extended lithospheric mantle. However, the magnitude of extension needed 
A. Model prediction for Carnarvon Basin

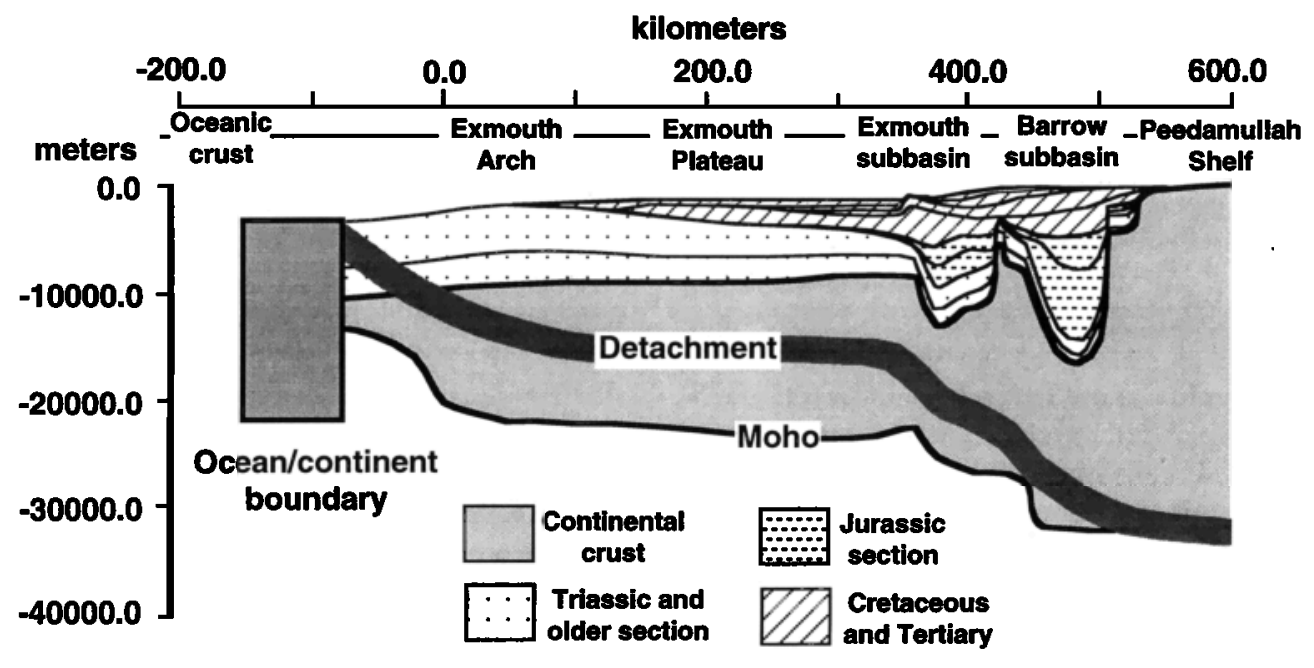

\section{B. Velocity-depth profile across Carnarvon Basin}

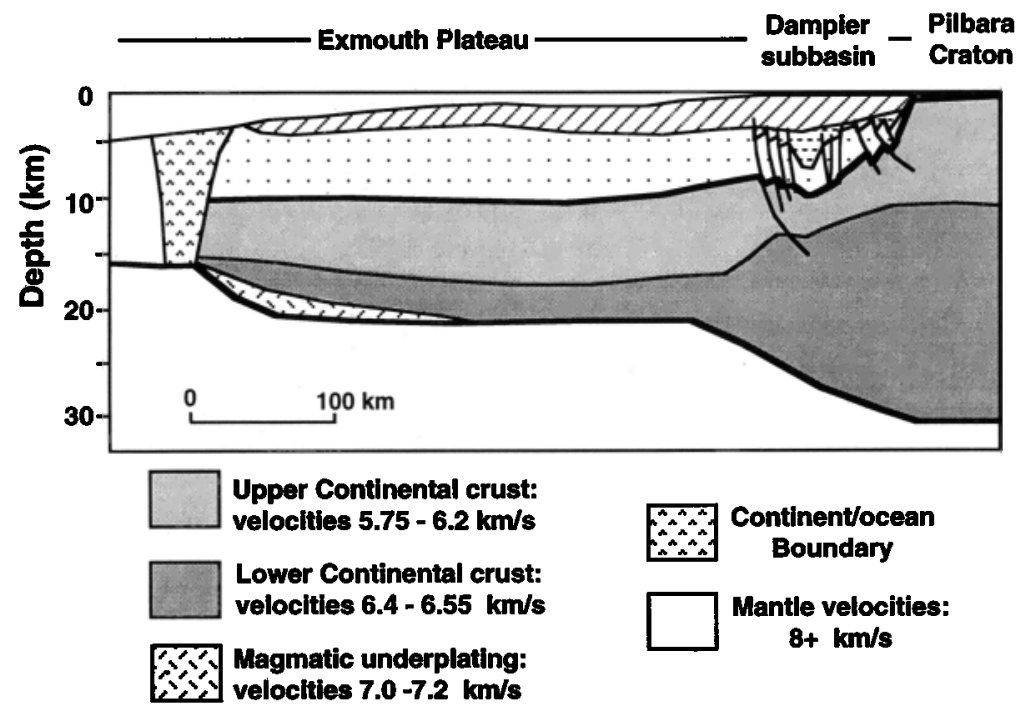

Figure 5. (a) General "ramp-flat-ramp" detachment geometry responsible for partitioning extension between the upper and lower plates during Tithonian-Valanginian extension. The detachment has a ramp-flatramp geometry such that it breached, or shoaled close to, the surface of the crust near the continent-ocean boundary. The "flat" component of the detachment occurs at midcrustal depths across the plateau and ramps beneath the Australian continent beneath the Peedamullah Shelf. The post-Valanginian subsidence increases toward the west away from the Exmouth Arch, which constrains the eastward dip of the detachment in this region. (b) Velocity depth profile across the Northern Carnarvon basin (modified from Stagg and Colwell [1994], reprinted by permission of the Australian Geological Survey Organisation). The cross section is projected along AGSO line 101-09 shown in Figure 1, which crosses the Dampier subbasin. The composite depth profile was derived from AGSO deep-seismic data, expanding spread profiles [Mutter et al., 1989], and Drummond [1981]. Note that the seismic velocities suggest that lower crustal thinning occurred across the Exmouth Plateau with the boundary between the upper and lower crust occurring at $\sim 15 \mathrm{~km}$ depth, consistent with the model predictions.

to generate the regional post-Valanginian subsidence (maximum $\beta(x)$ of 2.8 ) precludes it from being the thermal subsidence phase to the minor and laterally restrictive extension that occurred during Callovian time (maximum $\beta(x)$ of 1.15 , Plate 3). In addition, it is difficult to reconcile the long delay ( $\sim 30 \mathrm{Myr}$ ) between the Callovian extensional event and the onset of post-Valanginian thermal subsidence. Consequently, to model the distribution and magnitude of the post-
Valanginian subsidence required significant lower crustal and mantle extension across the Exmouth Plateau with only minor upper crustal deformation (Figure 4 and Plate 3 ). Such a depth-dependent distribution of extension (maximum $\delta(x)$ and $\beta(x)$ of 1.18 and 2.35 , respectively) implies the existence of an eastward dipping intracrustal detachment that effectively thins the lower crust and lithospheric mantle, generating thermal-type subsidence across the region (Figure 5). If $\beta(x)$ re- 
flected only mantle thinning (Plate 3 ), then there would be no net subsidence after the rift-induced heat dissipated from the region because basin formation in an extensional setting is ultimately the consequence of crustal thinning. In contrast to the depth-independent extension during late Permian time, the Tithonian depth-dependent extension required that negligible accommodation be created during the rifting event with large amounts of subsidence generated in the postrift phase (Plate 3). Because the lower crustal ductile extension and thermal uplift caused by lithospheric mantle thinning are of a comparable wavelength during the Tithonian-Valanginian rifting event, the thermal uplift approximately balances the riftinduced subsidence, which effectively delays the generation of accommodation until after rifting (Plate 2). The subsidence pattern requires that this detachment have a ramp-flat-ramp geometry so that it breached, or shoaled close to, the surface of the crust near the Gascoyne continent-ocean boundary (Figure 5). The upper crustal extension that balances the lower crustal and lithospheric mantle extension that occurred beneath the Northern Carnarvon basin is assumed to occur where the detachment breaches the crust. This breach must occur at or west of the continent-ocean boundary because large-scale brittle deformation is not observed across the Northern Carnarvon basin (Figure 5).

The eastward dip of the detachment is constrained by the eastward decrease in subsidence from the continent-ocean boundary to the Exmouth Arch (Figure 5). The magnitude and wavelength of this subsidence across the Exmouth Plateau away from the Exmouth Arch cannot be explained by flexural coupling across the continent-ocean boundary [Karner et al., 1991]. The "flat" component of the detachment occurs at midcrustal depths across the plateau, and its depth is constrained by the magnitude of the post-Valanginian subsidence. For example, if the depth of the detachment becomes shallower, then the magnitude of the post-Valanginian subsidence would increase similar to what occurs west of the Exmouth Arch (Figure 5). Likewise, if it was located deeper within the crust, then the subsidence would diminish. Toward the east, the detachment again ramps down merging with Moho beneath the Australian continent (i.e., Peedamullah Shelf). Its position is constrained by the distribution of Tithonian subsidence with minimal subsidence occurring east of the ramp (Figure 5). Seismic refraction work across the northwest Australian margin corroborates our interpretation of an intracrustal detachment and suggests that lower crustal thinning occurred across the Exmouth Plateau with the boundary between the upper and lower crust occurring at $\sim 15 \mathrm{~km}$ depth (Figure 5) [Exon et al., 1992; Stagg and Colwell, 1994].

An alternative hypothesis for the observed thermal subsidence is to have the northwest Australian margin situated over a hotspot during the early rift phases (Rhaetian and Callovian), and subsequently during the Valanginian to have the region move off the hotspot thereby allowing the thermally modified lithosphere to cool and subside. In effect, this process would allow thermal subsidence in the absence of crustal extension similar to the subsidence pattern observed at other margins influenced by documented hotspot activity [e.g., Karner et al., 1991; Driscoll et al., 1995]. Although petrologic evidence from ODP Legs 122 and 123 suggests that the tholeiites of the Argo and Gascoyne oceanic basins are consistent with higher than normal asthenospheric temperatures [Ludden and Dionne, 1992], geologic evidence supporting the existence of a hotspot and, more importantly, the timing of its arrival along the northwest Australian margin remains equivocal. For example, the emplacement of isolated volcanic constructs along the northwest Australian margin (e.g., Joey Rise and Platypus Spur) appears insufficient to explain the distribution and timing of the observed widespread subsidence because their emplacement postdates the onset of seafloor spreading. Furthermore, because the thermal input by a hotspot only delays the reequilibration of previously extended lithosphere, this delayed subsidence needs to be consistent with the cumulative distribution and magnitude of earlier crustal extensional events. The small magnitude and restrictive distribution of the late Triassic and middle Jurassic crustal extension across the Northern Carnarvon basin cannot explain the large, regional post-Valanginian subsidence observed across the basin (Plate 3 ). Therefore the observed subsidence across the Northern Carnarvon basin is best explained in terms of an intracrustal detachment.

Finally, our model results indicate that lower crustal plastic extension provides a viable mechanism to generate large "thermal-type" subsidence with little attendant brittle deformation. The lower crustal extension appears to be most dominant during the late stages of the rifting phase just prior to continental breakup because the upwelling of asthenospheric heat causes the quartz-rich lower crust to deform plastically. Tectonic and stratigraphic evidence from many conjugate margins (e.g., Newfoundland and Iberia conjugate margins) documents the existence of late stage regional subsidence with only minor accompanying brittle deformation and erosional truncation [Tankard and Welsink, 1987; Boillot et al., 1988; 1995; Driscoll et al., 1995]. To explain the distribution and magnitude of the "thermal-type" regional subsidence with little or no attendant brittle deformation requires significant lower crustal and mantle extension across and along these margins. For example, Tankard and Welsink [1987] proposed that a westward dipping detachment separated the Newfoundland upper plate from the Iberian lower plate (Figure 6). Likewise, Boillot and Winterer [1988] explained the discrepancy between the large regional subsidence ( $\beta=3.4$ to 4.6$)$ and the minimal brittle deformation ( $\delta=1.6$ to 1.9$)$ on the Iberian margin by having an eastward dipping detachment separating the Iberian upper plate from the Newfoundland lower plate (Figure 6). Based on the distribution and style of subsidence observed along the conjugate margins, both researchers interpret their margin as the upper plate [Tankard and Welsink, 1987; Boillot et al., 1988]. Similar observations have been made for the conjugate margins of the South Atlantic [Karner et al., 1997]. We propose that a diffuse zone (i.e., detachment) separates the brittle and ductile deformation in the crust which shoals in the region of maximum heat input. Therefore, depending on the location of athenospheric upwelling (e.g., the future ocean/continent boundary), the detachment will dip toward both margins. The balancing brittle deformation is focused in a narrow region adjacent to the continent-ocean boundary and soles into the detachment. The deformed continental crust in this region is highly intruded and overprinted by volcanism associated with rift-induced decompression melting. Vertically, the detachment separates brittle deformation above from plastic deformation below, and its depth migrates throughout the history of the rifting in response to the input of heat during the rifting process. Consequently, the horizontal displacement across the detachment varies spatially. In fact, along some portions of the detachment, there need not be significant differential motion across the detachment, only a difference in the style of deformation. To conclude, the terminology of upper and lower plate 


\section{A. Newfoundland Margin}

Galicia Margin

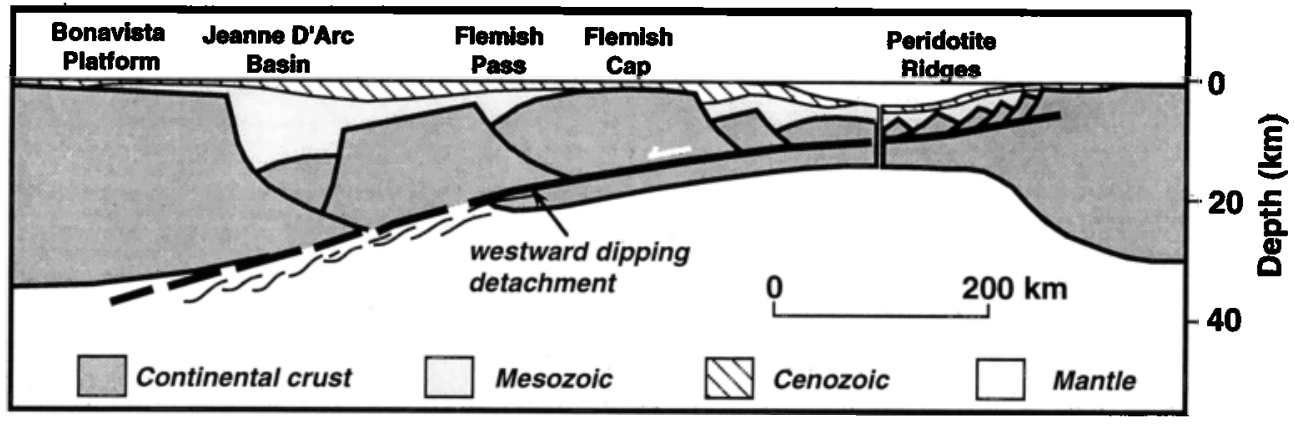

B. Newfoundland Margin

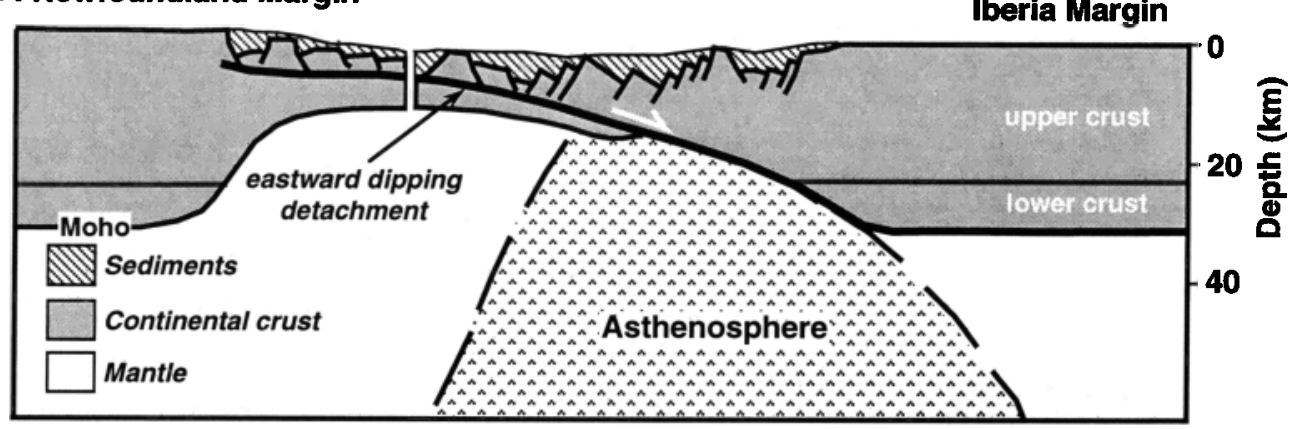

Figure 6. (a) Extensional model for the Newfoundland-Iberian conjugate margins derived from seismic reflection and well data suggesting extensional deformation along a western dipping detachment separating the Newfoundland upper plate from the Iberian lower plate (modified from Tankard and Welsink [1987], reprinted by permission of the American Association of Petroleum Geologists). This detachment model accounts for variable amounts of extension and the existence of late stage regional subsidence with only minor accompanying brittle deformation and erosional truncation. (b) Extensional model for the IberianNewfoundland conjugate margins suggesting extensional deformation along an eastern dipping detachment separating the Iberian upper plate from the Newfoundland lower plate (modified from Boillot et al. [1988] and Boillot and Winterer [1988], reprinted by permission of the Ocean Drilling Program). Boillot et al. [1988] explained the discrepancy between the large regional subsidence $(\beta=3.4$ to 4.6$)$ and the minimal brittle deformation ( $\delta=1.6$ to 1.9$)$ on the Iberian margin by having the Iberian margin be the upper plate. Likewise, Tankard and Welsink [1987] explained the discrepancy on the Newfoundland margin by having it be the upper plate. On the basis of subsidence style and distribution, both margins appear to be the upper plate.

is applicable when describing the morphology of the brittle deformation observed on conjugate margins. However, in terms of describing the distribution and style of subsidence observed on conjugate margins the use of upper and lower plate is misleading because both margins may display subsidence patterns that are characteristic of the upper plate (e.g., Newfoundland and Iberia).

\subsection{Late Mesozoic to Present Passive Margin Formation}

The Barrow delta was capped by the diachronous MardieBirdsong sands and overlying Muderong shales (Figure 3). The Muderong shale forms a widespread transgressive marine shale blanketing most of the Exmouth Plateau and northwest Australian margin. Overlying the Windalia sandstone is a radiolarian-rich siltstone containing glauconite and minor sandstone and clay stone, which in turn is overlain by the Gearle siltstone (Figure 3). As clastic input waned during the late Cretaceous-Tertiary, thick and widespread carbonatedominated sequences prograded out along the margin. These observations suggest that early Cretaceous deposition was occurring in an open marine outer shelf environment.

In addition to marking the onset of current-controlled deposition, the Gearle siltstone appears to be recording a minor episode of basin inversion in the Turonian (Figure 3). The forced fold observed in seismic line AGSO 110-12 (Plates 1 and 2) suggests minor uplift along the northwestern edge of the Exmouth subbasin.

\subsection{Model Predictions for Late Mesozoic and Tertiary Development}

The shift from terrigenous sediments to predominantly carbonate sediments along the Northern Carnarvon basin results from a relative sea level rise induced by the thermal reequilibration of the rifted lithosphere coupled with a systematic change in climatic conditions associated with the northward migration of the Australian continent. Without invoking some highly contrived stretching function across the margin it was not possible to generate the forced fold observed in seismic line AGSO 110-12 (Plates 1 and 2). The simplest explanation for this structure is inversion along the northwestern edge of the Exmouth subbasin during Turonian time. The amount of shortening associated with this reactivation is minor (i.e., shortening $\sim 500 \mathrm{~m}$ ). Nevertheless, it is not clear what tectonic event was responsible for the inversion when the northwest Australian margin should only be undergoing thermal subsidence. A possible explanation is the major plate reorganization 
that occurred between the Greater Indian and Australian plates at this time [Cande et al., 1989].

\section{Summary and Conclusions}

Our analysis of the tectonic and stratigraphic development of the Northern Carnarvon basin has led to the following predictions for its geological and thermal evolution:

1. Permian basin development across the Northern Carnarvon basin, $\sim 500 \mathrm{~km}$ across, is broadly distributed and represents the late stages of intracratonic basin formation across the region. The distribution and thickness of the Triassic Locker Shale and Mungaroo formation across the margin and, in particular, across the Peedamullah Shelf, are a direct consequence of the distribution and magnitude of lithospheric extension. The Locker and Mungaroo sequences thin toward the east by onlap. The modeled cross section for pre-late Triassic time in Plate 2 illustrates the Permo-Triassic succession that represents the synrift (Locker Shale) and postrift (Mungaroo formation) sequences associated with the Permian extension just prior to the late Triassic extensional episode across the northwest Australian margin.

2. A renewed episode of extension in the late Triassic affected the northwest Australian margin, generating an extensive along-strike network of basins. The extension was limited to a narrow portion of the margin producing the Barrow, Exmouth, and Dampier subbasins and the Argo, Gascoyne, and Cuvier rift basins. Even though the rift basins and subbasins were narrow and localized, their locations along the edge of the Peedamullah Shelf and the western edge of the Exmouth Plateau made them efficient traps for clastic sediment derived from the Australian continent to the east and the Greater Indian continent to the west. Consequently, the thick depositional wedges of the lower Dingo clay stone were confined to these basins, thus starving the Exmouth Plateau and Alpha Arch of clastic sediment. The Flinders Fault System was the basin-bounding fault system for the southern Barrow subbasin. The Alpha Arch, which delineates the western boundary of the southern Barrow subbasin and the eastern boundary of the Exmouth subbasin, represents both the collapsed hanging wall to the Flinders Fault System and the uplifted footwall to the Exmouth subbasin.

3. Callovian extension reactivated the border fault system that delineates the Barrow and Dampier subbasins. Once again, the main extensional deformation was restricted to the subbasins with minor but broadly distributed extension occurring across the Exmouth Plateau. The Flinders Fault System remained the active fault system for the southern Barrow subbasin. Within the Exmouth subbasin the dominant border fault system appears to have migrated from along the western edge of the Alpha Arch (late Triassic extension) to the eastern boundary of the Exmouth Plateau (middle Jurassic extension). Consequently, the depocenter for the upper Dingo clay stone was shifted toward the west with respect to the depocenter for the lower Dingo clay stone.

4. During Tithonian-Valanginian time the continental lithosphere along the western boundary of the Exmouth Plateau and the southwestern Australian margin was breached and oceanic lithosphere was emplaced. Minor fault reactivation occurred within the Barrow, Exmouth, and Dampier subbasins and across the Exmouth Plateau. The regional distribution and amplitude of the post-Valanginian subsidence are not consistent with the minor amounts of Tithonian-Valanginian brittle crustal extension. This pattern of subsidence indicates that significant lower crustal and mantle extension occurred across the Northern Carnarvon basin with only minor upper crustal deformation. Such a distribution of extension is best explained in terms of a eastward dipping intracrustal detachment that effectively thins the lower crust and upper mantle generating thermal-type subsidence across the region. Furthermore, the subsidence patterns require that this detachment have a ramp-flat-ramp geometry such that it breached the crust close to the position of the continent-ocean boundary. The "flat" component of the detachment occurred at midcrustal depths $(\sim 15 \mathrm{~km})$ across the plateau and ramped beneath the Australian continent beneath the Pilbara block.

5. Post-Valanginian thermal subsidence across the Northern Carnarvon basin engendered a relative sea level rise and is recorded by the shales overlying the Barrow sands. The Muderong shale forms a widespread transgressive marine unit and blankets most of the Exmouth Plateau and northwest Australian margin. As clastic input waned during the late CretaceousTertiary, thick and widespread carbonate-dominated sequences prograded across the open marine shelf environment.

6. Tectonic and stratigraphic evidence from many margins (e.g., northwest Australia, Grand Banks, Iberia, West Africa, Brazil) documents the existence of late stage regional subsidence with only minor accompanying brittle deformation and erosional truncation. To model the distribution and magnitude of the "thermal-type" regional subsidence with little or no attendant brittle deformation requires significant lower crustal and mantle extension across and along these margins. The lower crustal extension appears to be most dominant during the late stages of the rifting phase just prior to continental breakup. Lower crustal extension and the associated regional subsidence play an important role in controlling margin architecture and subsidence patterns. Finally, constraining the magnitude of lower crustal extension associated with intracrustal detachments along many conjugate margin pairs might explain the disparity in stretching estimates based on brittle deformation $(\delta)$ versus inferred thermal subsidence $(\beta)$, which, in turn, addresses the paradox that both sides of many conjugate margins appear to be the "upper plate."

Acknowledgments. We would like to dedicate this paper posthumously to Larry Sloss, the pioneer of sequence stratigraphy, who provided a critical and thorough review of this manuscript. We also acknowledge discussions with Jeffrey Weissel, Nick Christie-Blick, and Howard Stagg. David Falvey and Chi-Yuen Wang critically read an earlier version of this manuscript, and their comments are appreciated. We also thank the Australian Geological Survey Organization (AGSO), GECO-PRAKLA, and TGS Geophysical for granting us access to the seismic reflection and exploratory well data from the northern Carnarvon basin and surrounding region. This work was supported by the Minerals and Energy Research Institute of Western Australia (MERIWA) grant M260 and a research grant from Ampolex, BHP Petroleum, MOBIL, Santos, Texaco, WAPET, WMC Petroleum, and Woodside Offshore Petroleum. Additional funding was provided by the Palisades Geophysical Institute and the Office of Naval Research. Woods Hole Oceanographic Institution publication 9575. Lamont-Doherty Earth Observatory contribution 5713.

\section{References}

Abers, G. A., Possible seismogenic shallow-dipping normal faults in the Woodlark-D'Entrecasteaux extensional province, Papua New Guinea, Geology, 19, 1205-1208, 1991.

Anders, M. H., and N. Christie-Blick, Is the Sevier Desert reflection of west-central Utah a normal fault?, Geology, 22, 771-774, 1994.

Barber, P. M., Paleotectonic evolution and hydrocarbon genesis of the central Exmouth Plateau, $A P E A J ., 22,131-144,1982$. 
Boillot, G., and E. L. Winterer, Drilling on the Galicia Margin: Retrospect and prospect, Proc. Ocean Drill. Program, Sci. Results, 103, 809-828, 1988.

Boillot, G., J. Girardeau, and J. Kornprobst, Rifting of the Galicia Margin: Crustal thinning and emplacement of mantle rocks on the seafloor, Proc. Ocean Drill. Program, Sci. Results, 103, 741-755, 1988.

Boillot, G., M. O. Beslier, and J. Girardeau, Nature, structure and evolution of the ocean-continent boundary: The lesson of the west Galicia Margin (Spain), in Rifted Ocean-Continent Boundaries, edited by E. Banda et al., pp. 219-229, Kluwer Acad., Norwell, Mass., 1995.

Boote, D. R. D., and R. B. Kirk, Depositional wedge cycles on evolving plate margin, western and northwestern Australia, AAPG Bull., 73, 216-243, 1989.

Braun, J., and C. Beaumont, A physical explanation of the relation between flank uplifts and the breakup unconformity at rifted continental margins, Geology, 17, 760-764, 1989.

Buck, W. R., Flexural rotation of normal faults, Tectonics, 7, 959-973, 1988.

Cande, S. C., et al., Magnetic lineations of the world's ocean basins, AAPG map series, Am. Assoc. of Pet. Geol., Tulsa, Okla., 1989.

Christie-Blick, N., Onlap, offlap, and the origin of unconformitybounded depositional sequences, Mar. Geol., 97, 35-56, 1991.

Christie-Blick, N., and N. W. Driscoll, Sequence stratigraphy, Annu. Rev. Earth Planet. Sci., 23, 451-478, 1995.

Cochran, J. R., Effects of finite rifting times on the development of sedimentary basins, Earth Planet. Sci. Lett., 66, 289-302, 1983.

Cockbain, A. E., The North West Shelf, APEA J., 29, 529-545, 1989.

Copp, I. A., Depth to base Phanerozoic map of western Australia, explanatory notes, Rec. 1994/9, Geol. Surv. of West. Aust., Dep. of Miner. and Energy, East Perth, 1994.

Driscoll, N. W., and J. R. Hogg, Stratigraphic response to basin formation: Jeanne d'Arc Basin, offshore Newfoundland, in Hydrocar bon Habitat in Rift Basins, edited by J. J. Lambiase, Geol. Soc. Spec. Publ., 80, 145-163, 1995.

Driscoll, N. W., and G. D. Karner, Lower crustal extension along the northwest Australian margin: Tectonic and stratigraphic evidence for an eastward dipping detachment, Eos Trans. AGU, 76(46), Fall Meet. Suppl., F546, 1995.

Driscoll, N. W., J. R. Hogg, G. D. Kamer, and N. Christie-Blick, Extensional tectonics in the Jeanne d'Arc basin: Implications for the timing of break-up between Grand Banks and Iberia, in The Tectonics, Sedimentation and Palaeoceanography of the North Atlantic Region, edited by R. A. Scrutton et al., Geol. Soc. Spec. Publ., 90 1-28, 1995.

Drummond, B. J., Crustal structure of the Precambrian terrains of northwest Australia from seismic refraction data, BMR J. Aust. Geol. Geophys., 6(2), 123-135, 1981

Erskine, R., and P. R. Vail, Seismic stratigraphy of the Exmouth Plateau, in Atlas of Seismic Stratigraphy, vol. 2, edited by A. W. Bally, AAPG Stud. Geol., 27, 163-173, 1988.

Exon, N. F., U. von Rad, and U. von Stackelberg, The geological development of the passive margins of the Exmouth Plateau of northwest Australia, Mar. Geol., 47, 131-152, 1982.

Exon, N. F., B. U. Haq, and U. von Rad, Exmouth plateau revisited: Scientific drilling and geological framework, Proc. Ocean Drill. Program, Sci. Results, 122, 3-20, 1992.

Haq, B. U., Boyd, R. L., Exon, N. F., and von Rad, U., Evolution of the central Exmouth Plateau: A post-drilling perspective, Proc. Ocean Drill. Program, Sci. Results, 122, 801-816, 1992.

Jackson, J. A., Active normal faulting and crustal extension, in Continental Extenstional Tectonics, edited by M. P. Coward, J. F. Dewey, and P. L. Hancock, Geol. Soc. Special Publ. London, 28, 3-17, 1987.

Kamer, G. D., N. W. Driscoll, and J. Peirce, Gravity and magnetic signature of Broken Ridge, southeast Indian Ocean, Proc. Ocean Drill. Program, Sci. Results, 121, 681-686, 1991.

Karner, G. D., N. W. Driscoll, J. P. McGinnis, W. D. Brumbaugh, and N. Cameron, Tectonic significance of the syn-rift sedimentary packages across the Congo continental margin, Mar. Pet. Geol., in press, 1998.

Kopsen, E., Northern Carnarvon Basin hydrocarbon ditribution and future petroleum potential, in The Sedimentary Basins of Western Australia: Proceedings of Petroleum Exploration Society of Australia Symposium, Perth, edited by P. G. Purcell and R. R. Purcell, pp. 127-140, Pet. Explor. Soc. of Aust., Perth, Western Australia, 1994

Kopsen, E., and G. McGann, A review of the hydrocarbon habitat of the eastern and central Barrow-Dampier sub-basin, Western Australia, APEA J., 25, 154-176, 1985.
Kusznir, N. J., G. D. Karner, and S. Egan, Geometric, thermal and isostatic consequences of detachments in continental lithosphere extension and basin formation, in Sedimentary Basins and BasinForming Mechanisms, edited by C. Beaumont and A. J. Tankard Mem. Can. Soc. Pet. Geol., 12, 185-203, 1987.

Lister, G. S., and G. A. Davis, The origin of metamorphic complexes and detachment faults formed during Tertiary continental extensional in the northern Colorado River region, U.S.A., J. Struct. Geol., 11, 65-94, 1989.

Lister, G. S., M. A. Etheridge, and P. A. Symonds, Detachment models for the formation of passive continental margins, Tectonics, 10 1038-1064, 1991.

Ludden, J. N., and B. Dionne, The geochemistry of oceanic crust at the onset of rifting in the Indian Ocean, Proc. Ocean Drill. Program, Sci. Results, 123, 791-799, 1992.

McKenzie, D. P., Some remarks on the development of sedimentary basins, Earth Planet. Sci. Lett., 40, 25-32, 1978.

Mutter, J. C., R. L. Larson, and Northwest Australia Study Group Extension of the Exmouth Plateau, offshore northwestern Australia: Deep seismic reflection/refraction evidence for simple and pure shear mechanisms, Geology, 17, 15-18, 1989.

Royden, L., and C. E. Keen, Rifting processes and thermal evolution of the continental margin of eastern Canada determined from subsidence curves, Earth Planet. Sci. Lett., 51, 343-361, 1980.

Sloss, L. L., Forty years of sequence stratigraphy, Geol. Soc. Am. Bull., $100,1661-1665,1988$

Stagg, M. J., and J. B. Colwell, The structural foundations of the northern Carnarvon basin, in The Sedimentary Basins of Western Australia: Proceedings of Petroleum Exploration Society of Australia Symposium, Perth, edited by P. G. Purcell and R. R. Purcell, pp. 349-354, Pet. Explor. Soc. of Aust., 1994.

Tait, A. M., A depositional model for the Dupuy Member and the Barrow Group in the Barrow sub-basin, northwestern Australia, APEA J., 25, 282-290, 1985.

Tankard, A. J., and H. J. Welsink, Extensional tectonics and stratigraphy of Hibernia oil field, Grand Banks, Newfoundland, $A A P G$ Bull., 71, 1210-1232, 1987.

Vail, P. R., Seismic stratigraphy interpretation using sequence stratigraphy, I, Seismic stratigraphy interpretation procedure, in Atlas of Seismic Stratigraphy, vol. 3, edited by A. W. Bally, AAPG Stud. Geol. 27, 1-10, 1987.

Van Wagoner, J. C., R. M. Mitchum, K. M. Campion, and V. D. Rahmanian, Siliciclastic sequence stratigraphy in well logs, cores, and outcrops: Concepts for high-resolution correlation of time and facies, Methods Explor. Ser. 7, 55 pp., Am. Assoc. of Pet. Geol., Tulsa, Okla., 1990.

Veenstra, E., Rift and drift in the Dampier sub-basin: A seismic and structural interpretation, APEA J., 18, 177-189, 1985.

Wang, C., W. Hwang, and Y. Shi, Thermal evolution of a rift basin: The Tyrrhenian Sea, J. Geophys. Res., 94, 3991-4006, 1989.

Warris, B. J., The hydrocarbon potential of the Palaeozoic basins of Western Australia, APEA J., 33, 123-137, 1993.

Watts, A. B., G. D. Karner, and M. S. Steckler, Lithosphere flexure and the evolution of sedimentary basins, Philos. Trans. R. Soc. London, Ser. A, 305, 249-281, 1982.

Weissel, J. K., and G. D. Karner, Flexural uplift of rift flanks due to mechanical unloading of the lithosphere during extension, $J$. Geophys. Res., 94, 13,919-13,950, 1989.

Wernicke, B., Low-angle normal in the Basin and Range Province: Nappe tectonics in an extending orogen, Nature, 291, 645-648, 1981.

Wernicke, B., Cenozoic extensional tectonics of the US Cordillera, in The Geology of North America, vol. G3, The Cordillerian Orogen: Conterminous U.S., edited by B. C. Burchfiel, P. W. Lipman, and M. L. Zoback, pp. 553-581, Geol. Soc. of Am., Boulder, Colo., 1992. Willcox, J. B., and N. F. Exon, The regional geology of the Exmouth Plateau, APEA J., 16, 1-11, 1976.

N. W. Driscoll, Department of Geology and Geophysics, Woods Hole Oceanographic Institution, Woods Hole, MA 02453. (e-mail: ndriscoll@whoi.edu)

G. D. Karner, Lamont-Doherty Earth Observatory of Columbia University, Palisades, NY 10964.

(Received May 16, 1997; revised September 18, 1997; accepted November 10, 1997.) 